\title{
Entrepreneurship, Innovation and Regional Growth: A Network Theory
}

\author{
Robert Huggins \\ Cardiff University \\ Email: HugginsR@cardiff.ac.uk \\ Piers Thompson \\ Nottingham Trent University \\ Email: piers.thompson@ntu.ac.uk
}

\begin{abstract}
Despite the growing acknowledgement that entrepreneurship is an important driver of regional innovation and growth, the role of the networks in these processes has been less formally examined. In order to address this gap, this paper proposes that the relationship between entrepreneurship, innovation and regional growth is governed by a series of network dynamics. Drawing upon aspects of endogenous growth theory and the knowledge spillover theory of entrepreneurship, it is proposed that the nature of the networks formed by entrepreneurial firms is a key determinant of regional growth differentials. In particular, network capital, in the form of investments in strategic relations to gain access to knowledge, is considered to mediate the relationship between entrepreneurship and innovation-based regional growth. It is suggested that network dynamics should be further incorporated into theories concerning the link between knowledge spillovers, entrepreneurship and regional growth. The paper concludes with a series of theoretical, entrepreneurial and policy implications emerging from the study.
\end{abstract}

\section{Keywords}

networks; entrepreneurship; knowledge spillovers; innovation; regions; growth.

\section{JEL Classifcation}

L26; O31

Published in Small Business Economics please cite as:

Huggins, R. and Thompson, P. (2015) 'Entrepreneurship, innovation and regional growth: a network theory', Small Business Economics, 41 (5), 103-128.

The final publication is available at Springer via http://dx.doi.org/ 10.1007/s11187-015-9643-3 


\section{Introduction}

Innovation is commonly acknowledged to be a principal means by which regions foster economic growth and competitiveness (Capello and Nijkamp 2009; Cooke et al. 2011; Harris 2011). At the same time, it is increasingly suggested that entrepreneurship is also a key source of such growth (Audretsch and Thurik 2001; Audretsch and Keilbach 2004a; 2004b; Audretsch et al. 2006). Furthermore, alongside these perspectives there is a growing school of thought which suggests that the networks facilitating flows of knowledge within and across regions are a key source of innovation and growth (Huggins and Izushi 2007; Huggins and Johnston 2009). However, despite these developments, the role of networks within entrepreneurial models of regional growth has been less formally examined. Therefore, identifying a regional growth theory that integrates network dimensions alongside entrepreneurial and innovation related components may aid a more sophisticated understanding of the determinants of such growth, as well as the public policies that may be best attuned to their promotion.

Regions are increasingly considered to be important sources of economic development and organization in a globalized economy (Scott 1995; Cooke 1997; Amin 1999; Werker and Athreye 2004; Malecki 2007), and entrepreneurship, and the innovation it has the capacity to spawn, is increasingly considered to be a key factor underpinning the future growth trajectories of regions (Reynolds et al. 2001, 2002; Fritsch and Mueller 2004). The ability of regions to gain from the positive effects of entrepreneurship is likely to more than partly depend on their capability to turn knowledge into regional innovation and growth through the creation and dissemination of knowledge (Audretsch and Keilbach 2004a; 2004b; 2008). The innovation systems literature, especially the regional variety, highlights the flow of knowledge across organizations as a crucial factor for effective innovation (Freeman 1987; 1994; Lundvall 1995; Cooke 2004; Andersson and Karlsson 2007; Cooke et al. 2011; Harris 2011). However, although the regional innovation systems literature notes the importance of entrepreneurship as a feature of certain systems, it is not formally incorporated into these models (Qian et al. 2013). Indeed, even though the legacy and prevalence of Schumpeterian discourse has led to 'entrepreneurship' and 'innovation' more often than not being uttered in the same breath, especially in regional development circles, the connection between the two is usually implicitly, rather than explicitly, formulated.

In order to address this potential fuzziness, the aim of this paper is to argue that the relationship between entrepreneurship, innovation and regional economic growth is governed 
by a series of network dynamics relating to: (1) the nature of the firms established by entrepreneurs; (2) the nature of the knowledge accessed by firms; and (3) the spatial nature of the networks existing between those accessing and sourcing knowledge. Drawing principally upon aspects of endogenous growth theory and the knowledge spillover theory of entrepreneurship (Audretsch and Lehmann 2005; Acs et al. 2013), the paper establishes a series of network-based theoretical propositions contending that the nature of the knowledge networks held by entrepreneurial firms is a key driver of regional rates of innovation and subsequently growth. It is proposed that a key determinant of regional innovation and growth differentials is the capability and capacity of entrepreneurial firms within regions to establish the network capital required to innovate in an increasingly open environment. Entrepreneurial firms are defined as those firms with significant entrepreneurial traits such as being opportunity seeking, growth-oriented, and alert to new ideas (Eisenhardt and Schoonhoven 1996; Lechner and Dowling 2003). Network capital is defined as consisting of investments in strategic and calculative relations with other firms and organizations in order to gain access to knowledge to enhance expected economic returns, principally via innovation (Huggins et al. 2010; Huggins et al. 2012).

The paper proposes that network capital should be incorporated into theories concerning the link between knowledge spillovers, entrepreneurship, innovation and regional growth. The notion of network capital has been increasingly discussed and developed in the literature in recent years (e.g. Huggins 2010; Huggins and Johnston 2010; Kramera et al. 2011; Kramera and Revilla Diez 2012; Lawton Smith et al. 2012; Huggins et al. 2012; Fitjar and Huber 2014; Sleuwaegen and Boiardi 2014; Huggins and Thompson 2014) and provides a useful means for accounting for the nature and value of the interactions and relationships required for knowledge to both 'spillover' and be captured. As has been suggested by others, networks concern investments in 'interaction capability', and as intangible capital structures should be analyzed as capital objects (Westlund 1999). In this sense, the term network covers a wide range of interactions, and, as noted by Contractor and Lorange (2002), may be either horizontal or vertical. Alongside customers, suppliers, and members of professional networks, other potential actors with which firms may engage in knowledge-related networks include rival firms, private and public sector knowledge providers, and universities.

In order to achieve its aims the paper is structured as follows. Initially, it critiques the relevant literature relating to entrepreneurship and innovation, followed by a discussion arguing that innovation is generally a network-based phenomenon, requiring network capital to be effective. An examination of the connection between networks, knowledge spillovers 
and regional innovation follows, which highlights the growing relevance and scope for further development of the knowledge spillover theory of entrepreneurship in the context of network capital. The next three sections establish the core theoretical propositions underpinning the paper, presenting the firm, knowledge and spatial dynamics upon which network capital is founded. The penultimate section presents a model drawing together the generated propositions in order to indicate the role of networks, and specifically network capital, in promoting regional innovation and growth. The final section of the paper identifies and presents the theoretical implications of the study, along with the implications for entrepreneurs and policymakers.

\section{Entrepreneurship and Regional Innovation}

Based on the rise of endogenous models of economic growth, the sources of regional economic growth are increasingly considered to be based on the role that the production, distribution and use of knowledge play within and across regional economies (Grossman and Helpman 1994; Harris 2001; Ibert 2007; Zucker et al. 2007; Vaz and Nijkamp 2009; Antonelli et al. 2011). The knowledge-based economy is generally considered to consist of the sphere and nexus of activities and resources centred on, and geared toward, innovation (Romer 2007). With increasing globalisation, it can be argued that the regional level has become more important than nations in promoting and understanding innovation and economic growth (Storper 1997; Porter 2000; Camagni 2002; Scott and Storper 2003; Krugman 2005). Furthermore, entrepreneurship itself has a pronounced regional dimension, with differences in regional start-up rates, as well as differences in the success of start-ups and entrepreneurial attitudes, all indicating the role of the regional environment in fostering entrepreneurship (Armington and Acs 2002; Audretsch and Keilbach 2004a; Bosma and Schutjens 2011; Davidsson and Wiklund 1997; Fritsch and Mueller 2005; Fritsch and Wyrwich 2014; Huggins and Williams 2011; Mueller 2006; Mueller et al. 2008). Regions, therefore, can become 'incubators of new ideas' and provide opportunities for entrepreneurship to take place, as well as for discovering valuable new knowledge (Glaeser 2002; Ikeda 2008; Huggins and Williams 2011).

Entrepreneurship forms a part of endogenous modes of economic development consisting of activities, investment and systems arising and nurtured within a region, as opposed to being attracted from elsewhere (Audretsch 1995; Audretsch and Keilbach 2004a; Audretsch and Keilbach 2008; Audretsch and Lehmann 2005; Stam 2010; Ghio et al. 2014). As part of these modes, the capability of entrepreneurs to influence economic development is 
related to their capacity to access and exploit knowledge and generate innovation. Entrepreneurship is increasingly recognised as a crucial element in fostering economic growth (Audretsch et al. 2006; Carree and Thurik 2006; Romer 2007). Romer (2007, p. 128) emphasises the role of entrepreneurship by stating that "economic growth occurs whenever people take resources and rearrange them in ways that are valuable ... [It] springs from better recipes, not just more cooking”. In general, the process of entrepreneurship is widely considered to stimulate competition and drive innovation (Audretsch and Thurik 2001; Acs 2002; 2006; Powell 2007; Huggins and Williams 2011).

As already indicated, alongside the role of entrepreneurship, it is argued that economic growth also stems from the complementary role that knowledge and innovation play within and across economies (Andersson and Karlsson 2007; Asheim and Gertler 2005; Audretsch 2000; Cooke et al. 2004; 2011; Romer 1986; 1990). Knowledge is often considered to be a public good that frequently 'spills over' to other firms and individuals, allowing others to reap where they have not necessarily sown (Acs et al. 2009). Knowledge spillovers can be defined as the continuum between pure knowledge spillovers that are uncharged, unintended and not mediated by any market mechanism, and rent spillovers consisting of externalities that are at least partially paid for (Andersson and Ejermo 2005). In general, early incarnations of endogenous growth theory assumed that the spillover process is automatic; however, it is now recognised that it is a process driven by economic agents, in particular entrepreneurs (Audretsch and Keilbach 2004a; Braunerhjelm et al. 2010). Entrepreneurs and their firms convert available knowledge into economic knowledge (Braunerhjelm et al. 2010) and by doing so they guide the market, drive the selection processes, and create a further diversity and variety of knowledge forms (Schumpeter 1942; Kirzner 1973; Sautet and Kirzner 2006; Huggins and Williams 2011). Entrepreneurial firms contribute to diversity by commercialising knowledge (Acs and Plummer 2005), with a greater level of entrepreneurship producing greater variety and resultant rates of innovation and growth (Audretsch and Keilbach 2004a; 2004b). This is reflected in Braunerhjelm et al.'s (2010) notion of 'entrepreneurial efficiency', which pertains to the capability to exploit knowledge and transform it into goods due to the institutions, policies and path dependence present.

The 'innovation' or 'Schumpeterian' approach to economic growth suggests that markets tend toward disequilibrium as entrepreneurs contribute to the market's process of 'creative destruction' with new innovations replacing old technologies (Schumpeter 1934; Sobel et al. 2007). Successful regional economies, therefore, are characterised as those 
associated with efficient innovation systems resulting from high levels of entrepreneurship, while weaker economies are those with failing innovation systems and lower levels of entrepreneurship (Huggins et al. 2014). Regional innovation systems failure may occur due to the lack of coordinating and governance mechanisms underlying effective regional entrepreneurship and innovation-driven economies (Cooke 2004). In more entrepreneurial regions, network mechanisms are formed through the evolutionary interdependency emerging between entrepreneurs and other economic agents as a result of the recognition and necessity for knowledge and innovation-based interactions beyond the market - such mechanisms are less apparent in entrepreneurially weak regions (Cooke 2004; Porter 2003; Desrochers and Sautet 2004).

In general, regional development theories which do not incorporate entrepreneurial factors may fail to understand and identify key sources of regional innovation (Andersson 2005), with entrepreneurs in more innovative regional environments likely to be more alert to opportunities and to contribute to regional economic growth (Audretsch and Keilbach 2004a; Benneworth 2004; Lee et al. 2004).

\section{A Network-Based View of Innovation}

Within endogenous models of regional growth, knowledge is considered to spillover to other organizations, resulting in the generation of increasing returns, principally via innovation (Capello and Nijkamp 2009; Roberts and Setterfield 2010). Such knowledge, however, is not considered to be a purely public good, but one that is at least partially excludable - such as through the use of intellectual rights - given that organizations often consider there to be incentives for investing in its creation. Similarly, models seeking to explain innovation outputs, such as patents, are based on a knowledge production function in which organizations (i.e. firms) intentionally pursue new economic knowledge as a means of generating innovation (Griliches 1979; Audretsch 2000). This pursuit is generally considered to consist of the appropriation and exploitation of the knowledge spilling over from other organizations (other firms, universities and the like). Despite these theoretical developments, endogenous growth theorists throw little light on the mechanisms by which knowledge is transmitted across firms and organizations (Storper and Venables 2004), suggesting the need for a better understanding of the role of investments in spillover conduits in generating innovation and growth (Audretsch and Feldman 1996).

Emerging theories of the firm such as the knowledge-based view (Grant 1996) and extensions of the resource-based view (Eisenhardt and Schoonhoven 1996; Lavie 2006) 
recognize that the need to access knowledge is a key reason why firms build or enter networks with other organizations. These inter-organizational networks concern the interactions, relationships and ties existing between firms, and may arise through the need to access new technology, skills or expertise in order to keep pace with competitors (Ahuja 2000).

Inter-organizational networks in this context consist of the interactions and relationships organizations (principally firms) utilize to access knowledge beyond their market relationships. In other words, these networks consist of the means by which knowledge flows across organizations beyond the direct purchasing of it. As others have noted, inter-organizational networks of this kind generally come into being due to markets for knowledge being rare, since-with the exception of knowledge protected by property rights, such as patents and copyrights - they are difficult to create due to inherent asymmetry in the existing knowledge base of buyers and sellers (Arrow 1971; Grant 1996; Maskell 2000; Audretsch and Keilbach 2008; Malecki 2010). Inter-organizational networks, therefore, are increasingly found to act as a conduit facilitating the flow of skills, expertise, technology, R\&D and the like (Andersson and Karlsson 2007; Weterings and Ponds 2009).

Inter-organizational networks are an important aspect of the innovation process, with network scholars stressing that innovation is a complex process often requiring knowledge flow between organizations (Meagher and Rogers 2004, Lichtenthaler 2005; Sammarra and Biggiero 2008; Tomlinson 2010; Bergenholtz and Waldstrøm 2011). Increasingly, this process is viewed as a systemic undertaking, i.e. organizations no longer innovate in isolation but through a complex set of interactions with other organizations (Chesbrough 2003). It is through the networks underpinning these systemic processes that organizations access knowledge that they cannot, or do not wish to, generate internally. In recent years the term 'open innovation' has been coined to define the networked nature of innovation mechanisms. According to Chesbrough (2003, p. xxiv) open innovation is 'a paradigm that assumes that firms can and should use external ideas as well as internal ideas ... as the firms look to advance their technology'. Although existing evidence has mainly focused on open innovation in the context of large corporations, it is likely that it is a phenomenon equally applicable to a strata of more entrepreneurial firms (Laursen and Salter 2006; Perkmann and Walsh 2007).

It is possible to distinguish two general forms of inter-organizational network: (1) contact networks, through which organizations source knowledge and (2) alliance networks, through which organizations collaborate to innovate. Networks in the form of alliances 
usually concern formalized collaboration and joint ventures, and other relationships resulting in frequent and repeated interaction. Organizations gain advantages from networks by accessing the knowledge of the organizations in their network. This means that the advantage organizations are potentially able to gain is dependent upon the knowledge profile of their network (Stuart 2000; Ireland et al. 2002; Grant and Baden-Fuller 2004).

It has been proposed that the investment in calculative relations through which organizations gain access to knowledge to enhance expected economic returns is itself a form of capital, which can be termed network capital (Huggins 2010; Huggins and Johnston 2010; Kramera and Revilla Diez 2012; Kramera et al. 2011; Lawton Smith et al. 2012; Huggins et al. 2012; Huggins and Thompson 2014; Fitjar and Huber 2014; Sleuwaegen and Boiardi 2014). Some scholars have pointed to networks endowed with social capital - in the form of interpersonal relationships - as a key lubricator of knowledge spillovers (Iyer et al. 2005; Tura and Harmaakorpi 2005; Hauser et al. 2007; Lorenzen 2007; Walter et al. 2007; Tappeiner et al. 2008; Cantner et al. 2010; Vorley et al. 2012). However, although social capital may explain a degree of knowledge flow within a particular region, it does not necessarily account for the large proportion of the flow of economically beneficial knowledge (Bathelt et al. 2004; Weterings and Ponds 2009; Huber 2012). In this sense, network capital is a specific form of relational asset, and it is important not to conflate it with social capital, which largely refers to social governance mechanisms based on trust (Lorenzen 2007), while network capital consists of relationships and interactions between actors that are contingent upon the flow of knowledge between them.

When organizations deliberately invest in networks, these networks are necessarily different from social networks as they concern the development of relationships which Williamson (1993) refers to as 'calculative', since they consist of actions motivated by expected economic benefits (Hite and Hesterly 2001; Belussi and Sedita 2012). The notion of network capital is a response to the increased recognition that inter-organizational networks can be considered a strategic resource for firms (Mowery et al. 1996; Dyer and Singh 1998; Madhavan et al. 1998; Lorenzoni and Lipparini 1999; Kogut 2000; Gulati 2007). Research stemming from the field of strategic management has proposed an extension of the resourcebased view of the firm to account for external network capabilities (Gulati 1999; 2007; Gulati and Gargiulo 1999; Gulati et al. 2000; Lavie 2006).

The network capital concept is rooted in the recognition that the leveraging of interorganizational networks is an asset that can be shaped by firms, and is generated by their investments in calculative relations. This is significantly different from the type of social 
capital stemming from the social norms and customs present in a particular region (Capello and Faggian 2005; Tura and Harmaakorpi 2005). Network capital, consisting of relational assets in the form of strategic and calculative inter-organizational networks designed specifically to facilitate knowledge flow and innovation, better explains the means through which economically beneficial knowledge is accessed. Network capital is generated by the flow of knowledge stocks, and its accumulation is represented by the stock of these flows. In contrast to social networks, calculative networks often provide greater resource availability (Hite and Hesterly 2001), and network capital is likely to be highly significant to entrepreneurial firms as they seek to access and source knowledge.

\section{Networks, Knowledge Spillovers and Regional Innovation}

Knowledge accessing from external organizations is considered to have become increasingly important to entrepreneurial firms, which often cannot generate internally all the knowledge necessary for innovation (Freel 2000a; 2003; Hite and Hesterly 2001; Yli-Renko et al. 2001; Almeida et al. 2003; Huggins and Johnston 2009; 2010; Doran et al. 2012). Within an entrepreneurial firm environment, the role of inter-organizational networks and knowledge sources are recognized as potentially important assets for creating and sustaining innovation and competitiveness (Lechner and Dowling 2003). Also, there is growing evidence that network development is related to the growth of firms, particularly networks involving the flow of knowledge (Knoben and Oerlemans 2006).

Although the role of knowledge access and entrepreneurship are commonly considered to facilitate regional innovation, there have been few attempts to formalize this relationship. The major exception to this is the knowledge spillover theory of entrepreneurship (Audretsch and Lehmann 2005). The underlying premise of the knowledge spillover theory of entrepreneurship is that uncommercialized knowledge created in one organization serves as the source of knowledge generating entrepreneurial opportunities that ultimately contribute to innovation and economic growth (Audretsch and Lehmann 2005; Acs et al. 2013). This results in regional growth drawing upon the use of existing knowledge by both research and entrepreneurial labour to generate new knowledge and products at a rate determined by the institutions, policies and path dependent factors present (Braunerhjelm et al. 2010). As illustrated by Figure 1, a key feature of this theory is the existence of knowledge filter, which is the gap between new knowledge and that which Arrow (1962) refers to as economic or commercializable knowledge, which requires intentional and often complex efforts to access and assimilate (Audretsch and Lehmann 2005; Acs et al. 2013). A further 
premise of the theory is that knowledge access requires spatial proximity, with the localization of knowledge suggesting that entrepreneurship will tend to be spatially located within close geographic proximity to the source producing such knowledge (Audretsch et al. 2006; Acs et al. 2013).

\section{Figure 1 About Here}

In general, the knowledge spillover theory of entrepreneurship is important for its role in developing an understanding of how entrepreneurial connections to knowledge sources promote regional innovation and growth. However, it does not explore the nature and dynamics of the connections, and, as Hayter (2013) suggests, there is a need to integrate the role of networks into this theory. Furthermore, the extent to which the knowledge accessed by entrepreneurs and their firms continues to be principally of a localized nature can be contested. This said, there can be little doubt that, as hypothesized by knowledge spillover theory of entrepreneurship, innovative regions are generally populated by a higher number of knowledge-based firms and research intensive universities, providing greater opportunities for collaboration, networking, and knowledge sourcing (Keeble 1997). In contrast, low innovation regions tend to be organizationally and institutionally 'thin', with a lack of innovation-driven public or private sector entities, coupled with a high dependence on small and medium enterprises exhibiting low growth trajectories (Huggins and Johnston 2009). Accordingly, the least competitive and most peripheral regions are usually less well endowed with high quality knowledge providers (Hitchens et al. 1996; Huggins and Izushi 2007; Mahroum et al. 2008).

The differing spatial dynamics of knowledge sourcing activity suggests that network capital can be of either a local or global nature, with there being potentially some interdependency between the two. In particular, successful connectivity in global spaces is often considered to be the outcome of an initial system of localized interaction, whereby it is the knowledge crossing hallways and streets that initially catalyses intellectual exchange and knowledge transfer across oceans and continents (Glaeser et al. 1992). Linder and Strulik (2014) develop a model of economic development based on entrepreneurial network formation in which they indicate the importance of local connections for monitoring and enforcement purposes. As interconnectivity increases between agents, average path length falls as long-distance connections are made, reducing the relative clustering of connections. Unless the monitoring properties of these clustered network connections are replaced by 
formal institutions, Linder and Strulik (2014) show how economic development may stall. Clearly, similar patterns could be present in the knowledge networks of entrepreneurs.

In general, unless local networks keep abreast of knowledge emerging outside of their respective region, they run the risk of becoming rigid and outdated (Camagni 1991; Izushi 1997; Bathelt et al. 2004; Ter Wal and Boschma 2011). Even in those locations possessing a knowledge-rich environment there is evidence of a greater role being played by non-localized networks (Saxenian 2005). The key aspect of these developments is that the knowledge base of the world's most advanced local and regional economies is no longer necessarily local, but positioned within global knowledge networks (Wolfe and Gertler 2004; Huggins and Izushi 2007; Lorentzen 2008). There is also a growing school of thought that non-proximate actors are often equally, if not better, able to transfer strategically relevant and valuable knowledge across such spatial boundaries providing a high performing network structure is in place (McEvily and Zaheer 1999; Dunning 2000; Lissoni 2001; Davenport 2005; Palazzo 2005; Zaheer and Bell 2005; Teixeira et al. 2006; Torré 2008). Whereas firms with low levels of absorptive capacity (Cohen and Levinthal 1990) tend to network locally, those with higher absorptive capacity are often more connected to global networks (Drejer and Vinding 2007; Van Geenhuizen 2008).

Knowledge will tend to spill over beyond regional borders as a consequence of the existence of different forms of inter-regional contacts, with flows of inter-regional knowledge acting as important agents of innovation (Rodríguez-Pose and Crescenzi 2008). Furthermore, accessibility to extra-regional innovation tends to be positively associated with regional growth performance, with the 'amount of knowledge' available in a region reinforcing the effect of local innovative activities (Rodríguez-Pose and Crescenzi 2008). Similarly, it has been found that inflows of knowledge have a positive impact on the growth of a region, with this effect having a larger magnitude if neighboring regions also exhibit high growth rates (Badinger and Tondl 2002). Indeed, emerging research suggests that differences in regional growth rates can be explained by differences in knowledge accessibility within and across regions (Andersson and Karlsson 2007).

Based on the above, it seems clear that whilst the inter-organizational networks entrepreneurs and their firms establish provide them with access to the knowledge they require to innovate and grow, they may also ultimately contribute to the rates of innovation and growth in the region in which they are located. In other words, the nature of the network capital formed by entrepreneurial firms may be pivotal in determining the permeability of the knowledge filter proposed by the knowledge spillover theory of entrepreneurship, with 
regional rates of innovation consisting of the interaction between underlying rates of entrepreneurship and network capital.

Proposition 1: Regions with higher rates of entrepreneurship and network capital accumulation by entrepreneurial firms will experience higher rates of innovation.

Clearly, to theorise this proposed relationship further it is necessary to unpack and delineate the principal characteristics and components underlying the formation of network capital in entrepreneurial settings. In order to achieve this, the following three sections of paper focus on the dynamics of network capital in terms of the nature of entrepreneurial firms, the forms of knowledge they source, and the spatiality of the networks through which they access this knowledge.

\section{Firm Dynamics}

As a means of placing the evolution of networks in a context aligned with the evolution of the firm, it is important to consider the particular stages of development firms pass through. Industry life cycle theory contends that firms will generally fit within one of three broad phases - fluid, transitional, and mature - relating to the developmental stage of the industry within which they operate (Utterback and Abernathy 1975; Klepper 1997; Ter Wal and Boschma 2011; Balland et al. 2013). Others have pointed to a more specific life cycle of the firm (Agarwal and Gort 2002), with entrepreneurial researchers suggesting a number of typologies to capture differing developmental stages that can be summarized as consisting of four broad phases: (1) emergence; (2) growth; (3) maturity; and (4) death (Larson 1992; Hite and Hesterly 2001; Greve and Salaff 2003; Lechner and Dowling 2003; Jack et al. 2008; Presutti et al. 2013). Existing evidence suggests that during the emergence phase entrepreneurs build networks where ties combine calculative and social aspects (Johannisson et al. 2002; Schutjens and Stam 2003; Anderson et al. 2007; Anderson et al. 2010). This is to be expected, since for new firms the network requirements of both the firm and the firm's operator (i.e. the entrepreneur) are likely to coincide, encompassing both his/her social and economic needs and objectives (Jack 2005; Macpherson and Holt 2007; Jack et al. 2008; 2010). In growing and more mature firms, network capital is likely to become more evident through the formation of strategic alliances based on formalized collaboration and joint ventures, and other 'contracted' relationships involving equity and $R \& D$ agreements 
(Goerzen 2005; Goerzen and Beamish 2005; Grant 1996; Grant and Baden-Fuller 2004; Ireland et al. 2002; Stuart 2000).

Studies have found that firms with more dynamic configurations of both contact and alliance networks have a significantly superior innovation performance than those firms with more stable configurations (Huggins and Johnston 2010; Huggins et al. 2012). This indicates that more innovative firms are more likely to develop new contacts and alliances as a means of accessing and utilising the most appropriate and state-of-the-art knowledge. Therefore, although network stability is usually considered to be a positive feature of knowledge networks (Podolny and Page 1998), it appears that more innovative firms are avoiding the type of network inertia (DiMaggio and Powell 1983, Kim et al. 2006) and lock-in (Arthur 1989, Adler and Kwon 2002, Labianca and Brass 2006) that may stifle innovation. In general, network-oriented firms tend to enjoy superior innovation performance (Huggins et al. 2012), which adds weight to evidence on the link between the inter-organizational network activities of firms and their innovation capabilities (Powell et al. 1996, Stuart 2000, Pittaway et al. 2004, Obstfeld 2005). Dynamism, therefore, appears to be an important source of network capital and subsequent firm level innovation.

Proposition 2: Entrepreneurial firms with a greater capacity to accumulate network capital will achieve higher rates innovation.

Investments in network capital are likely to form a high proportion of the overall investments of entrepreneurial firms as they search, screen, and select knowledge sources and potential network partners (Drejer and Vinding 2007). In other words, the emergent phase of entrepreneurialism is a period of both high rates of network capital generation and subsequent new knowledge accumulation (March 1991; Nonaka and Takeuchi 1995; Quatraro 2010). Through the process of combing new and existing knowledge, firms not only raise their absorptive capacity rates but engage in the first rounds of innovation that lead to the growth phase (Cohen and Levinthal 1990; Zahra and George 2002).

The high frequency of knowledge sourcing and network capital development during the emergence phase, adds a degree of weight to the argument that these entrepreneurial firms are able to improve the permeability of the knowledge filter and to capture economically beneficial knowledge spilling over from other organizations (Arrow 1962; Audretsch and Lehmann 2005). However, an important addition to the knowledge filter argument is that entrepreneurs need to be proactively engaging in accessing this knowledge from their sources 
through investments in networks, rather than such knowledge being readily available to them (Teece 1998; Huggins 2010).

Proposition 3: Entrepreneurial firms with a greater capacity to accumulate network capital will improve the permeability of the knowledge filter.

\section{Knowledge Dynamics}

Knowledge can be generally defined as information that changes something or somebody, either by becoming grounds for action or by making an organization capable of different or more effective action (Drucker 1989). More generally, knowledge is broadly used as a scientific notion for the most important and dynamic driver of the modern economy (Nonaka and Takeuchi 1995). Of course, it can take many different forms, with one of the most familiar typologies suggesting that knowledge is either explicit/codified or tacit. In general, explicit knowledge refers to information that can be easily communicated among individuals, whereas tacit knowledge - such as skills, competence, and talents - is more difficult to directly communicate to someone else in a verbal or other symbolic form (Huggins and Izushi 2007; Nonaka and Takeuchi 1995). More codified forms of knowledge are usually considered to be relatively less space sensitive than tacit knowledge (Bathelt et al. 2004). Reductions in transport costs and improvements in communications are considered to have increased access to codified knowledge, rendering it less important as a source of competitive advantage. Tacit knowledge, on the other hand, is considered not to travel well, making it a key factor underlying ‘the geography of innovation’ (Asheim and Gertler 2005).

It is clearly important to understand how different forms of accessed knowledge contribute to the performance of entrepreneurial firms (Boschma et al. 2009), with the nature of the knowledge flowing and accessed through inter-organizational networks being an important determinant of the value organizations accrue from their network capital. Antonelli (2008) suggests that the first major shift in the economics of knowledge occurs when the notion of knowledge as a public good is challenged, and knowledge becomes regarded more as a quasi-private good with higher levels of natural appropriability and exclusivity. The creation of knowledge that is superior to other forms is now usually considered to emerge from collective processes characterized not only by partial appropriability and shared property rights, but also by the role of the intentional effort, participation and contribution of interactive agents to access and assimilate (Antonelli 2008). Indeed, knowledge, especially 
'combinatorial' knowledge, underlies the complexity of economic systems (Jensen et al. 2007; Martin and Sunley 2007; Mattes 2012).

Given this, it can be proposed the value of network capital to entrepreneurial firms will be determined not only by the superiority or excludability of the knowledge they are able to access through their inter-organizational networks, but also its miscibility, i.e. the capability for this knowledge to mixed/combined with different types of knowledge from different sources. The notion of combining knowledge through miscible flows is similar to Romer's (1996) idea of creating new recipes from existing knowledge, as well as harking back to Schumpeter's (1934) view of innovation as resulting from the carrying out of new combinations. In general, innovation is the outcome of a combinatorial search activity carried out across a technological space in which combinable elements reside (Quatraro 2010). In this sense, miscibility is based upon the rates of knowledge coherence and variety, with value being created when there is a 'collision' of knowledge (Frenken et al. 2007; Boschma et al. 2009; Quatraro 2010).

Entrepreneurial firms will receive a greater proportion of the value created the 'nearer'- in a cognitive sense (Boschma 2005) - they are to the collision. The successful recombining of existing knowledge in novel ways through networks (Nelson and Winter 1982) involving knowledge 'collisions' and 'transpositions' (Powell and Grodal 2005) is an example of the effective miscibility of knowledge. Similarly, combining different fields of knowledge creation, such as technology fusion (Kodama 1992), represents effective knowledge miscibility (Cantwell 2005). Network capital investments, however, may become ineffective if there is knowledge equivalence between organizations due to similarities in knowledge profiles, which results in network redundancy (Cowan et al. 2004). These inertial network forces highlight the issue of over-embeddedness, whereby the actors an organization is best connected to may not be best placed to provide solutions to current problems (Krackhardt 1994; Monge and Contractor 2003; Maurer and Ebers 2006).

Proposition 4: Entrepreneurial firms with a greater capacity to access superior, excludable and miscible forms of knowledge will achieve higher rates of innovation.

The excludability of knowledge may be compromised if it is allowed to 'leak' outside a particular network. Brown and Duguid (2001) distinguish between 'sticky' and leaky' knowledge, with sticky knowledge consisting of forms that are difficult to move, whilst leaky knowledge refers to the undesirable flow of knowledge to external sources. Without effective 
network management, knowledge may leak more freely out of a network than productively within it (Teece 1998; Fleming et al. 2007). Effective network management, through strategic and intentional investment in relationships, i.e. network capital building, is a mechanism for ensuring that value is captured rather than lost through inter-organizational networks (Lichtenthaler 2005; Teece 1998).

Similarly, the superiority of knowledge may be compromised as organizations within a network become increasingly familiar with each other's knowledge, and negative network effects may emerge, locking organizations into low value and unproductive networks, stifling the creation of new knowledge and innovation (Arthur 1989; Adler and Kwon 2002; Labianca and Brass 2006; Molina-Morales and Martínez-Fernández 2009). In order to continue to play a role in the innovation process, networks are often required to evolve to include new members and configurations to meet changing needs, expanding the network capital of engaged organizations (Hite and Hesterly 2001; Lechner and Dowling 2003). However, it should be noted that if investment (Linder and Strulik 2014) and labour (Frijters and Foster 2013) are withdrawn from other activities to achieve this, the development of network capital may result in a trade-off with current activities.

Proposition 5: Entrepreneurial firms with a greater capacity to manage inbound and outbound flows of knowledge will be more effective in accessing superior, excludable and miscible forms of knowledge.

\section{Spatial Dynamics}

A key dimension of the knowledge spillover theory of entrepreneurship is geographic distance, with the general argument being that knowledge spills over more easily within regions than at a distance beyond them (Jaffe et al. 1993). This suggests that local firms may often be embedded in regional knowledge channels (Breschi and Malerba 2001; Breschi and Lissoni 2009; Krätke 2010), with ready access to local public or private research institutes and universities being facilitated through local knowledge flow routes (Mueller 2006). However, while firms may benefit from local knowledge spillovers as an undirected and spontaneous 'buzz' (Storper and Venables 2004), they may also need to consciously build non-local 'pipelines' to tap into knowledge from outside their region (Bathelt et al. 2004).

The constraining effect of distance on knowledge flow and transfer is considered by some to be gradually diminishing, and there is increasing evidence of the heightened role being played by international knowledge sourcing networks in many places across the globe 
(Athreye 2004; Doloreux 2004; Garnsey and Heffernan 2005; Saxenian 2005; Fitjar and Rodríguez-Pose 2011). Many firms do not acquire their knowledge from within geographically proximate areas, particularly those based upon innovation-driven growth where knowledge is often sourced internationally (Davenport 2005). If applicable knowledge is available locally, firms and other organizations will attempt to source it; if not they will look elsewhere (Drejer and Vinding 2007).

Knowledge spillovers are generally found to be greater in the presence of knowledge investments, and vice versa, with those regions possessing high knowledge investments experiencing a higher level of knowledge spillover - with interregional spillovers contributing significantly to regional knowledge production (Bathelt et al. 2004). A growing base of evidence suggests that knowledge is increasingly flowing across regional clusters, resulting in heightened global knowledge connectivity. This has led some to question the view that tacit knowledge transfer is confined to local milieus, arguing that firms source tacit knowledge from selected providers located outside the local milieu by investing in the building of new channels of communication (Wolfe and Gertler 2004; Fontes 2005; Gertler and Levitte 2005; Fitjar and Rodriguez-Pose 2011). It can be suggested, therefore, that although knowledge spillovers may take place across regions, it is usually through more selective routes (Audretsch and Feldman 1996; Bode 2004; Audretsch and Lehmann 2005). For instance, the concept of 'temporary clusters', whereby strategic network building occurs through conferences, trade fairs, exhibitions and the like, highlights the importance of network capital and access to knowledge through global pipelines (Maskell et al. 2006; Bathelt and Schuldt 2008; 2010; Power and Jansson 2008; Torré 2008; Rinallo and Golfetto 2011; Schuldt and Bathelt 2011).

Proposition 6: Entrepreneurial firms with a greater capacity to access high quality knowledge through selected routes and channels regardless of the geographic location of knowledge sources will achieve higher rates of innovation.

These intra- and inter-regional network patterns indicate that the geographic location of entrepreneurial firms will influence the innovation output regions accrue from these networks. For example, if all the knowledge flowing through a network consists of firms and organizations based in the same region, it is likely that all the benefits will accrue to this region. If some firms and organizations are based in another region, it is likely that some of the benefits of this knowledge flow will also accrue to this other region. Therefore, it may 
well be the case that the knowledge flowing from organizations in this other region is more economically valuable (in terms of its superiority, excludability or miscibility) than that available in the focus region, with the advantages in terms of the nature of the knowledge outweighing any disadvantages in terms of location (Boschma and Ter Wal 2007; Weterings and Ponds 2009; Huggins et al. 2010; Belussi and Sedita 2012).

This indicates that the types of inter-organizational networks which entrepreneurial firms engage in, and the nature of the knowledge flowing through these networks, will impact on levels of regional innovation. Therefore, regional innovation cannot be modeled in isolation, but must be considered in relation to the networks existing across regions, as illustrated by Figure 2. At a regional level, localized flows of knowledge may result in a higher proportion of the output distributed across networks being captured and retained within a particular region, i.e. by local organizations. However, potential limitations in the appropriateness of knowledge accessible through localized pools mean that access to appropriate knowledge may be inversely related to the geographical proximity of appropriate knowledge sources.

Proposition 7: Regional innovation rates are partly a function of the spatial configuration of the knowledge networks established by entrepreneurial firms.

Figure 2 About Here

\section{Endogenous Regional Growth, Entrepreneurship and Network Capital: A Model}

This section establishes a model connecting the propositions generated above to theorise on the means by which entrepreneurship and network capital facilitate innovation-driven endogenous regional growth. Furthermore, it goes some way to developing a more mathematical treatment of these relationships. Based on the established propositions, a theoretical step forward would be to acknowledge the mediating role of network capital within the knowledge spillover theory of entrepreneurship, incorporating the network dynamics influencing the knowledge filter.

Figure 3 presents a model indicating the propositions laid out previously in relation to the different aspects of the linkages between knowledge supply, the knowledge filter, entrepreneurship, network capital and regional innovation and growth. The key role played by network capital is its mediation of the relationship between entrepreneurship and regional innovation. Within the knowledge spillover theory of entrepreneurship uncommercialised 
knowledge is converted into economic knowledge by entrepreneurs (Acs et al. 2013). This can be represented by a direct link from knowledge to entrepreneurship and a direct link to regional innovation and growth (as previously illustrated by Figure 1). The importance of network capital means that Proposition 1 is reflected by the role of both network capital and entrepreneurship in generating regional innovation and growth (Huggins 2010).

\section{Figure 3 About Here}

As Proposition 2 suggests, the continuing accumulation of network capital will enable entrepreneurial firms to access and use new knowledge to generate innovations (Kim et al. 2006; Huggins et al. 2012), with investments in network capital stemming from entrepreneurship. The link between network capital and the knowledge filter is vital with regard to ensuring that knowledge flows are effectively managed, as outlined by Proposition 5 (Fleming et al. 2007; Lichtenthaler 2005; Teece 1998), as well as ensuring the permeability of the knowledge filter and sufficient safeguards against the undesirable appropriation of a firm's own knowledge by another actor. This increases the prospect that more high quality knowledge will be accessed (Proposition 3), which will also be economically beneficial knowledge based on its superior, excludable and miscible nature, as outlined by Proposition 4 (Huggins 2010).

Although knowledge may be easier to transmit over shorter distances (Drejer and Vinding 2007), Proposition 6 highlights the role and importance of network capital in acquiring information over greater distances (Bathelt et al. 2004; Maskell et al. 2006). Knowledge acquired from less spatially proximate locations is likely to have the advantage of in terms of its nature, especially its superiority and excludability. This benefit, recognised in Proposition 7 is represented by the link from spatial location to the regional innovation and growth achieved (Boschma and Ter Wal 2007).

In general, endogenous models of regional growth have followed in the footsteps of Romer (1986; 1990) and Lucas (1988), with a focus on the role of endowments of knowledge and human capital in explaining innovation and growth differentials (Andersson and Karlsson 2007; Storper 2010; Storper and Scott 2009; Capello and Nijkamp 2009; Harris 2011). As indicated earlier, more recently, there has been significant attention given to adding the role of entrepreneurs into these equations, particularly through the inclusion of the concept of entrepreneurship capital (Audretsch and Keilbach 2004a; 2004b; 2008). However, there has been little attention given to the role of networks, or the connection between network capital 
and entrepreneurship capital. Therefore, the model presented here is an attempt to fill this gap, but in order to further consider these relationships it is useful to establish a more mathematical model of these connections, building on existing relevant models. Although the following does not set out to create a full mathematical model of endogenous growth (partly due to space restrictions), it does seek to consider how networks can be incorporated into existing growth models that already account for entrepreneurial factors. In particular, it builds upon Braunerhjelm et al.’s (2010) attempt to incorporate the role of entrepreneurs into a model of endogenous growth, indicating that growth rates becomes a function of the labour allocated to research $\left(L_{R}\right)$ and entrepreneurship $\left(L_{E}\right)$ :

$$
g=\frac{\dot{A}}{A}=\sigma_{R} L_{R}+\sigma_{E} L_{E}^{\gamma}
$$

Where $A$ is the current stock of knowledge and the variables $\sigma_{R}$ and $\sigma_{E}$ are the efficiency of the economy with regard to research and entrepreneurship respectively, stemming from regional policies, institutions and path dependence. This represents how well incumbents and new entrants (entrepreneurs) transform knowledge into innovation. It is assumed that there are diminishing returns to scale from entrepreneurship $(0<\gamma<1)$. The choice of whether or not to become an entrepreneur is a function of their entrepreneurial ability $\left(\bar{e}_{i}\right)$, the current state of knowledge $(A)$ and the efficiency of the economy in relation to entrepreneurial activities $\left(\sigma_{E}\right)$.

Whilst Braunerhjelm et al.'s (2010) model represents an excellent and valid entrepreneurial twist to endogenous growth modelling it does not capture the influence of networks. Furthermore, whilst others have sought to integrate networks into a growth model, they do not explicitly incorporate entrepreneurship (Huggins and Thompson 2014). As a means of integrating both networks and entrepreneurship, Ha and Howitt' s (2007) general model of output can be used as starting base, which is given by:

$$
Y=K^{\alpha}\left(A h\left(L-L_{R}-L_{E}\right)\right)^{1-\alpha}
$$

This means that output is a function of capital $(K)$, labour $(L)$, current knowledge $(A)$ and human capital (h). As with Braunerhjelm et al. (2010), equation (2) assumes that labour allocated to research and entrepreneurship is not available for final production. This assumption might be relaxed to some degree for entrepreneurship labour where small business owners are likely to be heavily involved in day-to-day activities as well as activities associated with knowledge creation. The relative importance of capital inputs is reflected by 
the $\alpha$ term. The growth in knowledge is driven by the current state of knowledge $(A)$ and the R\&D inputs available $(X)$, as well as Braunerhjelm et al.’s (2010) entrepreneurial inputs $(U)$.

$$
g=\frac{\dot{A}}{A}=\sigma_{R}\left(\frac{X}{L^{\beta}}\right)^{\kappa} A^{\phi-1}+\sigma_{E}\left(\frac{U}{L^{\beta}}\right)^{\theta} A^{\gamma-1}
$$

The importance of $R \& D$ and entrepreneurial inputs are represented by $\kappa$ and $\theta$ respectively. Returns to scale from existing knowledge through each knowledge formation mechanism are given by $\phi$ and $\gamma \cdot \beta$ is the coefficient representing product proliferation. As before, $\sigma_{R}$ and $\sigma_{E}$ represent the efficiency or productivity of incumbent firms and entrepreneurs in generating new knowledge.

Huggins and Thompson (2014) suggest that $\mathrm{R} \& D$ inputs in region $(X)$ are a combination of the labour employed in research $\left(L_{R}\right)$ and the network capital of incumbent firms $(W)$. In other words, network capital plays a similar role to entrepreneurial inputs alongside the entrepreneurial labour $\left(L_{E}\right)$.

$$
\begin{aligned}
& X=L_{R}{ }^{\psi} W^{(1-\psi)} \\
& U=L_{E}{ }^{\rho} W^{(1-\rho)}
\end{aligned}
$$

Where $\psi$ and $\rho$ are the relative importance of $\mathrm{R} \& \mathrm{D}$ and entrepreneurial labour as inputs into the relevant knowledge production mechanisms. In this case, the value of the total network capital available in a region will be a combination of that stemming from both within the region $\left(W_{L}\right)$ and less spatially proximate sources $\left(W_{N L}\right)$. Each of these will be a function of the connections made by firms in the region $(C)$ and the value of these connections $(V)$, as shown below for the case of regional network capital. Following prior studies, it is assumed that connectivity is a function of the proportion (Q) of capital (Linder and Strulik 2014) and labour (Frijters and Foster 2013) committed to forming and maintaining these connections:

$$
W_{L, t+1}=\bar{V}_{L}\left[\sum_{i=0}^{I} C_{L, t+1}^{\eta}\right]^{v}=\bar{V}_{L}\left[\sum_{i=0}^{I}\left(\left(Q K_{t}\right)^{T}\left(Q\left(L_{t}-L_{R, t}-L_{E, t}\right)\right)^{D}+(Q \pi) C_{L, t-1}\right)^{\eta}\right]^{v}
$$

It is expected that individual firms may suffer from diminishing returns to scale in relation to their connections $(\eta<1)$. This reflects informational redundancy and the management of knowledge flows becoming an issue (McFadyen and Cannella 2004). However, for the region as a whole there may be increasing returns to scale from better connectivity $(v>1)$. In terms of the connections formed, a lag is added into the relationship to represent the time required to reap any benefits from the resources that contribute to forming new connections. The first element relating to the number of connections represents the capital and labour committed to 
creating new connections, with $T$ and $D$ representing the importance of each to the production of new connections. The second term reflects the existing network connections retained from the previous period. It is assumed that a proportion of these connections remain after a period $(0<\pi<1)$ if they are maintained. If no resources are committed $(Q=0)$, all connections will be lost.

The network capital of the region, however, will depend on the average value of the information received, which, as described above, reflects the superiority $\left(V_{L s}\right)$, excludability $\left(V_{L e}\right)$ or miscibility $\left(V_{L m}\right)$ of the knowledge accessed.

$$
\bar{V}_{L}=h \bar{V}_{L s}^{\delta} \bar{V}_{L e}^{\xi} \bar{V}_{L m}^{\tau}
$$

Where $\delta, \xi$ and $\tau$ represent the relative importance of the average level of superiority, excludability and miscibility, respectively. The need for absorptive capacity (Cohen and Levinthal 1990) is represented by human capital entering the function $(h)$.

The need to allocate capital and labour to the maintenance of network connections reduces that available for producing final goods to $(1-Q)$ of the total:

$$
Y=(1-Q) K^{\alpha}\left(A h(1-Q)\left(L-L_{R}-L_{E}\right)\right)^{1-\alpha}
$$

This means that, as with any investment, enterprises have to balance current output against future output. Further extensions could be included to account for separate efforts being required to maintain local and non-local connections, as well as asymmetry in the costs of achieving this for each. The role of maintaining connections may also be taken by entrepreneurs, reducing the entrepreneurial labour input into direct knowledge creation.

\section{Discussion and Conclusion}

This final section of the paper discusses the implications of the propositions and model presented above from the perspective of theoretical development, as well as the implications for entrepreneurs and their firms and recommendations for policy progression. Each of these is summarised in Table 1, as well as being outlined in more detail below.

Table 1 About Here

\section{Theoretical Implications}

Overall, the paper argues that the innovation performance of entrepreneurial firms, and subsequently the innovation and growth performance of the regions in which they are located, 
is significantly related to network capital investment in dynamically configured interorganizational interactions and relationships. The extant evidence suggests that three interrelated dynamics are of particular relevance: (1) the nature of the firms established by entrepreneurs; (2) the nature of the knowledge accessed by firms; and (3) the spatial nature of the networks existing between those accessing and sourcing knowledge.

It is further argued that there are multiple mechanisms underlying the formation and development of inter-organizational networks by entrepreneurial firms, and it is through a range of complementary networks that firms are able to appropriately access and apply knowledge, and subsequently develop innovative goods and services. Furthermore, entrepreneurs identify and mobilize the uniqueness of their knowledge base according to three underlying characteristics: the superiority, excludability and miscibility of knowledge i.e. the capability to mix and combine different types of knowledge from different sources with their own knowledge stocks.

In terms of improving our understanding of the unevenness of rates of innovation and economic growth across regions, it is proposed that regional innovation rates are a function of the interaction between the rate of entrepreneurship and the rate of network capital accumulation by entrepreneurs and their firms, as manifested by the capability to access external knowledge. This suggests that the interaction between rates of entrepreneurship and network capital should be more explicitly integrated into endogenous models of regional growth, as outlined in the previous section.

It is further proposed that regional innovation rates are partly a function of the spatial configuration of the knowledge networks established by entrepreneurial firms, with the innovation capability of entrepreneurial firms being partly a function of their capacity to access superior, excludable and miscible forms of knowledge regardless of the geographic location of knowledge sources. One implication of this is that endogenous models of regional growth should seek to incorporate variables to account for inter-regional flows of knowledge. For example, there is the potential for models to not only analyse knowledge spillovers from the perspective of the geographic space and distance over which such knowledge flows but also the 'network space' encompassing these flows. In this case, network space can be conceptualised as principally consisting of the structure of the relationships, interactions and ties underlying network capital, with emerging evidence suggesting that geographic space and network space are intertwined factors underlying the evolution of knowledge networks (Huggins et al. 2012). 
From the perspective of entrepreneurs and their firms it is proposed that the capability of entrepreneurial firms to improve the permeability of the knowledge filter is a function of the investments they make in accumulating network capital. As indicated above, and in line with the arguments of those such as Hayter (2013), this suggests that the knowledge spillover theory of entrepreneurship should be extended to further account for the networks entrepreneurs and their firms are required to establish to access external knowledge. In general, whilst the knowledge spillover theory of entrepreneurship concentrates on explaining and understanding the existence and importance of entrepreneurs to innovation and growth (Audretsch and Keilbach 2008; Audretsch and Lehmann 2005), the theoretical observations proposed in this paper are focused more on explaining and understanding how networks promote and mediate the relationship between innovation at firm and regional level. In essence, both theories are principally centred on determining how flows of knowledge, rather than the traditional focus on stocks (Romer 1986; 1990), impact on innovation and economic performance at a range of levels, and therefore they are closely aligned in their core objectives.

The innovation capability of entrepreneurial firms is proposed to be partly a function of their capacity to accumulate network capital. This suggests two implications in terms of networks theories that seek to explain firm level differences in rates of innovation (Freel 2000b; Freel and Harrison 2006; Rogers 2004; Ozman 2009; Pittaway et al. 2004; Tomlinson 2010). First, they may benefit from conceptualising inter-firm and inter-organisational networks as a form of capital asset that allows access to external knowledge resources. This echoes the work of Lavie (2006) who has called for the conceptualisation of an extended resource-based view of the firm to include the value accrued through external networks, and that of Gulati (1999; 2007) who has further proposed that such networks form a firm level resource.

Second, network theories of firm level differences in rates of innovation should seek to account further for differences in the quality of the knowledge accessed from external sources, especially in terms of the potential economic benefits associated with particular knowledge forms - although due to its intangible, non-standardized and inseparable nature (Howells 2012) it is acknowledged that this is no easy task.

Finally, it is proposed that the capability of entrepreneurial firms to access economically beneficial knowledge is partly a function of their capacity to strategically manage incoming and outgoing flows of knowledge. This suggests that theories of strategic entrepreneurial management need to ensure that the role of network management is 
embedded within future conceptual frameworks. To an extent, this has occurred through the emergence of notions of intellectual capital and knowledge management, which have placed a central onus on strategies to effectively exploit knowledge, although often focusing on knowledge internal to the firm (Daft and Weick 1984; Stewart 1997; Bontis et al. 1999; Marr et al. 2004). Also, these concepts have usually been established to explain and understand network and knowledge management in large firm environments, with less scholarly research focused on these issues in entrepreneurial settings (Huggins and Weir 2007).

\section{Entrepreneurial and Policy Implications}

Alongside the theoretical implications, the analysis suggests a number of practical implications for entrepreneurs and their firms. First off, it is clear that those entrepreneurs seeking to innovate are likely to benefit from the accumulation of network capital, which will facilitate better access to economically beneficial knowledge. However, entrepreneurs should be aware of the trade-offs that may exist between accessing knowledge that is relatively easy to source and absorb, and knowledge which may be more difficult to identify and integrate, but potentially offers far greater economic returns. Given this, and echoing the comments above, entrepreneurs should ensure that management systems are in place to effectively search, screen and select the most appropriate knowledge to flow in and out of their firms. It is likely that in order to access the highest quality knowledge, entrepreneurs should seek to invest in a balanced portfolio of networks encompassing both local and more global geographic connections. However, this balance, and the success of firms in generating innovation, will be partly governed by the regional environment in which entrepreneurial firms are located. Similarly, the networks established by entrepreneurs are likely to impact upon the innovation capability and economic growth capacity not only of their home region, but also the performance of other regions where there are firms and organisations with which they network.

These practical implications for entrepreneurs raise a number of potential recommendations for future policy that can be said to operate at the nexus of regional innovation and entrepreneurship policymaking. Interestingly, Asheim and Isaksen (2003) argue that endogenous regional development is unlikely to occur holistically without public intervention to stimulate network formation. Nauwelaers and Wintjes (2003) classify regional innovation policies according to two core types: (1) system-oriented (regional) - principally network building and brokering, cluster development, innovation system development, cooperation and mobility; (2) firm-oriented - principally access to human capital (e.g. 
business support and advice), financial capital (e.g. risk capital, loans or subsidies), or physical capital (e.g. incubators, research and technology centres).

The latter firm-oriented policies are generally aligned with a range of recognised policies focused on promoting entrepreneurship in its broader context; that is, not simply in terms of business start-ups or small-business growth (Bridge et al. 2003; Audretsch et al. 2007; Huggins and Williams 2009; 2011). From the perspective of promoting the accumulation of effective network capital across entrepreneurial firms, both types are likely to be required to operate in tandem, with a need for coordination across policies (Nauwelaers and Wintjes 2003).

It is clear that regional rates of innovation are likely to be relatively high in those regions where entrepreneurial firms are able to establish networks facilitating access to a pool of high quality knowledge. In regions with lagging rates of innovation, entrepreneurial firms are likely to face barriers in accessing such knowledge, especially through networks within their own region. This implies the need for policy intervention to be made available to entrepreneurial firms in regions with low rates innovation.

More generally, across regions of all types there is a need to ensure the necessary support to help firms develop their capability to establish effective networks. For example, if entrepreneurs within a region are unable to assimilate knowledge from their internal base with that accessible from other organizations, there is a potential role for intervention in the form of innovation policies that act as an 'emulsifier' allowing different types of knowledge to be more effectively combined.

Similarly, policy should support firms to ensure they are capable of accessing the most appropriate and suitable knowledge for their innovation needs. In particular, policymakers need to become increasingly aware of the need for entrepreneurial firms to establish a portfolio of both sustained and more dynamic ephemeral knowledge sources. Without this balance, entrepreneurial firms run the risk of becoming locked-in to using outdated knowledge that undermines their innovative capabilities (Freel 2000b; Pittaway et al. 2004).

Alongside this, there is a clear and on-going requirement for regional policy to ensure sufficient absorptive capacity and human capital within the regional base of entrepreneurial firms (Cohen and Levinthal 1990; Giuliani 2005; Zahra and George 2002). Therefore, regional innovation policies must be closely meshed with regional skills strategies to continue efforts to up-skill the workforces and human capital of entrepreneurial firms - particularly 
with regard to management development - ensuring they are able to identify, absorb and transform into innovation the wealth of knowledge potentially available to them.

Furthermore, although entrepreneurial firms are unlikely to be able to bear the cost of full-time knowledge gatekeepers (Tushman and Katz 1980; Rychen and Zimmermann 2008; Belussi et al. 2010), more can be done to educate firms in the key principles of network management, as a feature of more general knowledge management practices. There are growing applied and professional disciplines related to the management of networks and knowledge flows, which should be supported through public policy (Huggins and Weir 2007).

Entrepreneurial firms should be further encouraged to source the most relevant knowledge wherever it is located. For some years, regional innovation policy has focused on the cluster model of development (Porter 1990; Martin and Sunley 2003), which has led to there being little concern from policymakers with supporting more global connections. Policy initiatives, therefore, should widen their regional focus and embrace more spatially open and connected network systems. Efforts to internationalise the trading activities of entrepreneurial firms (McDougall and Oviatt 2000; Oviatt and McDougall 2005) should be complemented by a greater effort to internationalise their knowledge and innovation networks. Support should also be made available for engagement with global communities of practice. Communities of practice are becoming ever more international in their dimensions, and to remain innovative entrepreneurial firms must become better integrated into their respective global villages (Bathelt et al. 2004).

Finally, regional policy can play a role in empowering entrepreneurial firms. Entrepreneurial firms are often fearful of engaging in knowledge exchange partnerships with larger firms, particularly multinationals, due to worries concerning the exploitation of their knowledge base without receiving appropriate levels of financial reward (Lechner and Dowling 2003; Huggins and Johnston 2010). Traditionally, the assertion of intellectual property has been seen as the key means by which entrepreneurial firms are able to protect their knowledge. However, due to increasing problems of asserting rights in many sectors (e.g. services) and the cost and time implications of patenting and licensing agreements (Hipp and Grupp 2005), this is not an option for all entrepreneurial firms, especially as larger firms are adopting open innovation strategies. To an extent, the traditional intellectual property support available to entrepreneurial firms is likely to become less relevant as open innovation and open sourcing become ever more prevalent business practices (Chesbrough 2003; von Hippel 2005), and new policy initiatives are required to support these firms in ensuring they 
are equitably treated when establishing joint knowledge-based venture and strategic alliances with larger firms.

\section{Avenues for Future Research}

In term of future research, this paper has presented a theoretical model for understanding how networks, and network capital, mediate the relationship between entrepreneurship and regional innovation. Although based on a critique of a wide range of literature, there is a need for empirical work to further substantiate this link. Empirical work on the knowledge spillover theory of entrepreneurship has specifically focused on innovations stemming from university created knowledge, and it would appear pertinent to test the network-based view of regional innovation by this same criteria, with future empirical analyses addressing the extent to which the density and structure of network capital within and across regions influences regional innovation and growth performance, and conversely the extent to which the network structure of entrepreneurial firms is influenced by the regional environment in which they are located.

\section{Acknowledgements}

The authors are grateful to the Economic and Social Research Council (ESRC) (Grant Award Reference RES-171-25-0023) and the Smart Specialisation for Regional Innovation project funded by the European Union under the FP7 Cooperation Programme: Social Sciences and the Humanities (Grant Number 320131) for partly funding the research upon which this article is based.

\section{References}

Acs, Z. J. (2002). Innovation and the Growth of Cities. Cheltenham: Edward Elgar.

Acs, Z. J. (2006). How is Entrepreneurship Good for Economic Growth? Innovations, 1(1), 97-107. doi:10.1162/itgg.2006.1.1.97

Acs, Z. J., \& Plummer, L.A. (2005). Penetrating the knowledge filter in regional economies. The Annals of Regional Science, 39(3), 439-456. doi: 10.1007/s00168-005-0245-x

Acs, Z. J., Audretsch, D. B., \& Lehmann, E. E. (2013). The knowledge spillover theory of entrepreneurship. Small Business Economics, 41(4), 757-774. doi: 10.1007/s11187013-9505-9

Acs, Z. J., Braunerhjelm, P., Audretsch, D. B., \& Carlsson, B. (2009). The knowledge spillover theory of entrepreneurship. Small Business Economics, 32(1), 15-30. doi: 10.1007/s11187-008-9157-3

Adler, P. S., \& Kwon, S. W. (2002). Social capital: prospects for a new concept. Academy of Management Review, 27(1), 17-40. doi: 10.5465/AMR.2002.5922314

Agarwal. R., \& Gort, M. (2002). Firm and Product Life Cycles and Firm Survival. American Economic Review, 92(2), 184-190. doi: 10.1257/000282802320189221 
Ahuja, G. (2000). The duality of collaboration: Inducements and opportunities in the formation of interfirm linkages. Strategic Management Journal, 21(3), 317-343. doi: 10.1002/(SICI)1097-0266(200003)21:3<317::AID-SMJ90>3.0.CO;2-B

Almeida, P., Dokko, G., \& Rosenkopf, L. (2003). Startup size and the mechanisms of external learning: increasing opportunity and decreasing ability? Research Policy, 32(2), 301-315. doi:10.1016/S0048-7333(02)00101-4

Amin, A. (1999). An Institutionalist Perspective on Regional Economic Development. International Journal of Urban and Regional Research, 23(2), 365-378. doi: 10.1111/1468-2427.00201

Anderson, A., Park, J., \& Jack, S. (2007). Entrepreneurial social capital: conceptualizing social capital in new high-tech firms. International Small Business Journal, 25(3), 245-272. doi: 10.1177/0266242607076526

Anderson, A., Dodd, S. D., \& Jack, S. (2010). Network practices and entrepreneurial growth, Scandinavian Journal of Management, 26(2), 121-133. doi: 10.1016/j.scaman.2010.01.005

Andersson, D. E. (2005). The spatial nature of entrepreneurship. Quarterly Journal of Austrian Economics, 8(2), 21-34. doi: 10.1007/s12113-005-1020-7

Andersson, M., \& Ejermo, O. (2005). How does accessibility to knowledge sources affect the innovativeness of corporations? Evidence from Sweden. Annals of Regional Science 39(4), 741-765. doi: 10.1007/s00168-005-0025-7

Andersson, M., \& Karlsson, C. (2007). Knowledge in regional economic growth: the role of knowledge accessibility, Industry and Innovation, 14(2), 129-149. doi: 10.1080/13662710701252450

Antonelli, C. (2008). Localised Technological Change: Towards the Economics of Complexity. London: Routledge.

Antonelli, C., Patrucco, P., \& Quatraro, A. (2011). Productivity growth and pecuniary knowledge externalities: An empirical analysis of agglomeration economies in European regions. Economic Geography, 87(1), 23-50. doi: 10.1111/j.19448287.2010.01104.x

Armington, C., \& Acs, Z. J. (2002). The determinants of regional variation in new firm formation. Regional Studies, 36(1), 33-45. doi: 10.1080/00343400120099843

Arrow, K. J. (1962). Economic welfare and the allocation of resources for invention. In:Nelson, R. (Ed.), The Rate and Direction of Inventive Activity. Princeton: Princeton University Press.

Arrow, K. J. (1971). Essays in the Theory of Risk-Bearing. Amsterdam: North-Holland.

Arthur, B. (1989). Competing technologies and lock-in by historical events: The dynamics of allocation under increasing returns. Economic Journal, 99(394), 116-131.

Asheim, B., \& Gertler, M. (2005). The geography of innovation: Regional innovation systems. In The Oxford Handbook of Innovation, Fagerberg J, Mowery DC, Nelson RR (eds). Oxford: Oxford University Press.

Asheim, B., \& Isaksen, A. (2003). SMEs and the regional dimension of innovation. In B. Asheim, A. Isaksen, C. Nauwelaers, \& F. Tödtling (Eds.), Regional innovation policy for small-medium enterprises (pp. 21-48). London: Edward Elgar.

Athreye, S. (2004). Agglomeration and growth: A study of the Cambridge hi-tech cluster. In T. Bresnahan, \& A. Gambardella (Eds.), Building high-tech clusters Silicon Valley and beyond (pp. 121-159). Cambridge \& New York: Cambridge University Press.

Audretsch, D. B. (1995). Innovation and industry evolution. Cambridge, MA: MIT Press.

Audretsch, D. B. (2000). Knowledge, Globalization, and Regions: An economist's perspective. In J. H. Dunning (Ed.), Regions, Globalization, and the KnowledgeBased Economy (pp. 63-81). Oxford: Oxford University Press. 
Audretsch, D. B., \& Feldman, M. P. (1996). R\&D spillovers and the geography of innovation and production. American Economic Review, 86(3), 630-640.

Audretsch, D. B., \& Keilbach, M. (2004a). Entrepreneurship capital and economic performance. Regional Studies, 38(8), 949-959. doi: 10.1080/0034340042000280956

Audretsch, D. B., \& Keilbach, M. (2004b). Entrepreneurship and regional growth: an evolutionary interpretation. Journal of Evolutionary Economics, 14(5), 605-616. doi: 10.1007/s00191-004-0228-6

Audretsch, D. B., \& Keilbach, M. (2008). Resolving the knowledge paradox: Knowledgespillover entrepreneurship and economic growth, Research Policy, 37(10), 16971705. doi: 10.1016/j.respol.2008.08.008

Audretsch, D. B., \& Lehmann, E. E. (2005). Does the Knowledge Spillover Theory of Entrepreneurship hold for regions? Research Policy, 34(8), 1191-1202. doi: 10.1016/j.respol.2005.03.012

Audretsch, D. B., \& Thurik, A. R. (2001). Linking entrepreneurship to growth. STI working paper, Paris: OECD.

Audretsch, D. B., Grilo, I., \& Thurik, A. R. (2007). Explaining entrepreneurship and the role of policy: a framework. In D. B. Audretsch et al. (Eds.), The Handbook of Research on Entrepreneurship Policy (pp. 1-17). Cheltenham and Northampton, MA.

Audretsch, D. B., Keilbach, M., \& Lehmann, E. E. (2006). Entrepreneurship and Economic Growth. Oxford: Oxford University Press.

Badinger, H., \& Tondl, G. (2002). Trade, human capital and innovation: the engines of European regional growth in the 1990s. In B. Fingleton (Ed.), European Regional Growth (pp. 215-240). Heidelberg: Springer.

Balland, P.-A., De Vaan, M., \& Boschma, R. (2013). The dynamics of interfirm networks along the industry life cycle: The case of the global video game industry, 1987-2007. Journal of Economic Geography, 13(5), 741-765. doi:10.1093/jeg/lbs023.

Bathelt, H., \& Schuldt, N. (2008). Between luminaires and meat grinders: International trade fairs as temporary clusters. Regional Studies, 42(6), 853-868. doi: $10.1080 / 00343400701543298$

Bathelt, H., \& Schuldt, N. (2010). International trade fairs and global buzz, Part I: Ecology of global buzz. European Planning Studies, 18(12), 1957-1974. doi: 10.1080/09654313.2010.515815

Bathelt, H., Malmberg, A., \& Maskell, P. (2004). Clusters and knowledge: Local buzz, global pipelines and the process of knowledge creation. Progress in Human Geography, 28(1), 31-56. doi: 10.1191/0309132504ph469oa

Belussi, F., \& Sedita, S. R. (2012). Industrial districts as open learning systems: Combining emergent and deliberate knowledge structures. Regional Studies, 46(2), 165-184. doi: 10.1080/00343404.2010.497133

Belussi, F., Sammarra, A., \& Sedita, S. R. (2010). Learning at the boundaries in an "Open Regional Innovation System": A focus on firms' innovation strategies in the Emilia Romagna life science industry. Research Policy, 39(6), 710-721. doi: 10.1016/j.respol.2010.01.014

Benneworth, P. (2004). In what sense 'regional development?': entrepreneurship, underdevelopment and strong tradition in the periphery. Entrepreneurship and Regional Development, 16(6), 439-458. doi: 10.1080/0898562042000249786

Bergenholtz, C., \& Waldstrøm, C. (2011). Inter-organizational network studies: A literature review. Industry and Innovation, 18(6), 539-562. doi: 10.1080/13662716.2011.591966

Bode, E. (2004). The spatial pattern of localized R\&D spillovers: an empirical investigation for Germany. Journal of Economic Geography, 4(1), 43-64. doi: 10.1093/jeg/4.1.43 
Bontis, N., Dragonetti, N. C., Jacobsen, K., \& Roos, G. (1999). The knowledge toolbox: A review of the tools available to measure and manage intangible resources. European Management Journal, 17(4), 391-402. doi: 10.1016/S0263-2373(99)00019-5

Boschma, R. A. (2005). Proximity and innovation: A critical assessment. Regional Studies, 39(1), 61-74. doi: 10.1080/0034340052000320887

Boschma, R., \& Ter Wal, A. (2007). Knowledge networks and innovative performance in an industrial district: The Case of a footwear district in the South of Italy. Industry and Innovation, 14(2), 177-199. doi: 10.1080/13662710701253441

Boschma, R., Eriksson, R., \& Lindgren, U. (2009). How does labour mobility affect the performance of plants? The importance of relatedness and geographical proximity. Journal of Economic Geography, 9(2), 169-190. doi: 10.1093/jeg/lbn041

Bosma N., \& Schutjens, V. (2011). Understanding regional variation in entrepreneurial activity and entrepreneurial attitude in Europe. Annals of Regional Science, 47(3), 711-742. doi: 10.1007/s00168-010-0375-7

Braunerhjelm, P., Acs, Z. J., Audretsch, D. B., \& Carlsson, B. (2010). The missing link: knowledge diffusion and entrepreneurship in endogenous growth. Small Business Economics, 34(2), 105-125. doi: 10.1007/s11187-009-9235-1

Breschi, S., \& Lissoni, F. (2009). Mobility of skilled workers and co-invention networks: an anatomy of localized knowledge flows. Journal of Economic Geography, 9(4), 439468. doi: 10.1093/jeg/lbp008

Breschi, S., \& Malerba, F. (2001). The geography of innovation and economic clustering: some introductory notes. Industrial and Corporate Change, 10(4), 817-834. doi: 10.1093/icc/10.4.817

Bridge, S., O’Neill, K., \& Cromie, S. (2003). Understanding Enterprise, Entrepreneurship and Small Business. Basingstoke: Palgrave Macmillan.

Brown, J. S., \& Duguid, P. (2001). Knowledge and organization: a social practice perspective. Organizational Science, 12(2), 198-213. doi: 10.1287/orsc.12.2.198.10116

Camagni, R. P. (1991). Local 'milieu', uncertainty and innovation networks: Towards a new dynamic theory of space. In Camagni (Ed.), Innovation networks (pp. 121-142). London: Belhaven Press.

Camagni, R. P. (2002). On the concept of territorial competitiveness: sound or misleading? Urban Studies, 39(13), 2395-2411. doi: 10.1080/0042098022000027022

Cantner, U., Conti, E., \& Meder, A. (2010). Networks and innovation: the role of social assets in explaining firms' innovative capacity. European Planning Studies, 18(12), 1937-1956. doi: 10.1080/09654313.2010.515795

Cantwell, J. (2005). Innovation and Competitiveness, in Fagerberg, J., Mowery, D.C. and Nelson, R.R. (eds) The Oxford Handbook of Innovation, Oxford: Oxford University Press.

Capello, R., \& Faggian, A. (2005). Collective learning and relational capital in local innovation processes. Regional Studies, 39(1), 75-87. doi: $10.1080 / 0034340052000320851$

Capello, R., \& Nijkamp, P. (eds) (2009). Handbook of Regional Growth and Development Theories. Cheltenham: Edward Elgar.

Carree, M., \& Thurik, A. R. (2006). Understanding the role of entrepreneurship for economic growth. In M. A. Carree, \& A. R. Thurik (Eds.), The Handbook of Entrepreneurship and Economic Growth (International Library of Entrepreneurship Series) (pp. ixxix). Cheltenham: Edward Elgar.

Chesbrough, H. (2003). Open Innovation: The New Imperative for Creating and Profiting from Technology. Boston, MA: Harvard Business School Press. 
Cohen, W. M., \& Levinthal, D. A. (1990). Absorptive capacity: a new perspective on learning and innovation, Administrative Science Quarterly, 35(1), 128-152. doi: $10.2307 / 2393553$

Contractor, F., \& Lorange, P. (2002). The growth of alliances in the knowledge-based economy. International Business Review, 11(4), 485-502. doi: 10.1016/S09695931(02)00021-5

Cooke, P. (1997). Regions in a global market: the experiences of Wales and Baden Württemberg. Review of International Political Economy, 4(2), 349-381. doi: $10.1080 / 096922997347814$

Cooke, P. (2004). Regional innovation systems - an evolutionary approach. In P. Cooke, M. Heidenreich, \& H. Braczyk (Ed.), Regional innovation systems: The role of governance in a globalised world (pp. 1-18). London: Routledge.

Cooke, P., Heidenreich, M., \& Braczyk, H. (eds.) (2004). Regional Innovation Systems: The role of Governance in a Globalised World. London: Routledge.

Cooke, P., Asheim, B., Boschma, R., Martin, R., Schwartz, D., \& Tödtling, F. (Eds.) (2011). Handbook of Regional Innovation and Growth, Cheltenham: Edward Elgar.

Cowan, R., Jonard, N., \& Zimmerman, J-B. (2004). Networks as emergent structures from bilateral collaboration. Maastricht: Maastricht Economic Research Institute on Innovation and Technology.

Daft, R. L., \& Weick, K. E. (1984). Toward a model of organizations as interpretation systems. Academy of Management Review, 9(2), 284-295. doi: 10.5465/AMR.1984.4277657

Davenport, S. (2005). Exploring the role of proximity in SME knowledge-acquisition. Research Policy, 34(5), 683-701. doi: 10.1016/j.respol.2005.03.006

Davidsson, P., \& Wiklund, J. (1997). Values, beliefs and regional variations in new firm formation rates. Journal of Economic Psychology, 18(2/3), 179-199. doi: 10.1016/S0167-4870(97)00004-4

Desrochers, P., \& Sautet, F. (2004). Cluster-Based Economic Strategy, Facilitation Policy and the Market Process. The Review of Austrian Economics, 17(2/3), 233-245. doi: 10.1023/B:RAEC.0000026833.26220.2d

DiMaggio, P. J., \& Powell, W. W. (1983). The iron cage revisited: institutional isomorphism and collective rationality in organizational fields. American Sociological Review, 48(2), 147-160.

Doloreux, D. (2004). Regional innovation systems in Canada: a comparative study. Regional Studies, 38(5), 479-492. doi: 10.1080/0143116042000229267

Doran, J., Jordan, D., \& O'Leary, E. (2012). The effects of the frequency of spatially proximate and distant interaction on innovation by Irish SMEs. Entrepreneurship and Regional Development, 24(7-8), 705-727. doi: 10.1080/08985626.2012.710261

Drejer, I., \& Vinding, A. L. (2007). Searching near and far: determinants of innovative firms' propensity to collaborate across geographical distance. Industry and Innovation, 14(3), 259-275. doi: 10.1080/13662710701369205

Drucker, P. F. (1989). The New Realities: in Government and Politics/In Economics and Business/In Society and World View. New York, NY: Harper and Row.

Dunning, J. H. (2000). Regions, globalization, and the knowledge economy: the issues stated. In J. H. Dunning (Ed.), Regions, globalization, and the knowledge-based economy (pp. 7-41). Oxford: Oxford University Press.

Dyer, J. H., \& Singh, H. (1998). The relational view: co-operative strategy and sources of interorganizational competitive advantage. Academy of Management Review, 23(4), 660-679. doi: 10.5465/AMR.1998.1255632 
Eisenhardt, K. M., \& Schoonhoven, C. B. (1996). Resource-based View of Strategic Alliance Formation: Strategic and Social Effects in Entrepreneurial Firms. Organization Science, 7(2), 136-150. doi: 10.1287/orsc.7.2.136

Fitjar, R. D., \& Huber, F. (2014). Global pipelines for innovation: insights from the case of Norway. Journal of Economic Geography, doi:10.1093/jeg/lbu017.

Fitjar, R. D., \& Rodriguez-Pose, A. (2011). When local interaction does not suffice: sources of firm innovation in urban Norway. Environment and Planning A, 43(6), 1248-1267. doi: 10.1068/a43516

Fleming, L., King, C., \& Juda, A. I. (2007). Small worlds and regional innovation. Organization Science, 18(6), 938-954. doi: 10.1287/orsc.1070.0289

Fontes, M. (2005). Distant networking: the knowledge acquisition strategies of 'out-cluster' biotechnology firms. European Planning Studies, 13(6), 899-920. doi: 10.1080/09654310500188498

Freel, M. S. (2000a). Do small innovating firms outperform non-innovators? Small Business Economics, 14(3), 195-210. doi: 10.1023/A:1008100206266

Freel, M. S. (2000b). External linkages and product innovation in small manufacturing firms. Entrepreneurship and Regional Development, 12(3), 245-266. doi: $10.1080 / 089856200413482$

Freel, M. S. (2003). Sectoral patterns of small firm innovation, networking and proximity. Research Policy, 32(5), 751-770. doi: 10.1016/S0048-7333(02)00084-7

Freel, M. S., \& Harrison, R. T. (2006). Innovation and cooperation in the small firm sector: Evidence from 'Northern Britain'. Regional Studies, 40(4), 289-305. doi: 10.1080/00343400600725095

Freeman, C. (1987). Technology, policy, and economic performance: Lessons from Japan. London: Pinter Publishers.

Freeman, C. (1994). The economics of technical change. Cambridge Journal of Economics, 18(5), 463-514.

Frenken, K., van Oort, F.G., \& Verburg, T. (2007). Related variety, unrelated variety and regional economic growth. Regional Studies, 41(5), 685-697. doi: 10.1080/00343400601120296

Frijters, P., \& Foster, G. (2013). Economic theory of greed, love, groups, and networks, Cambridge: Cambridge University Press.

Fritsch, M., \& Mueller, P. (2004). The Effects of new business formation on regional development over time. Regional Studies, 38(8), 961-976. doi: $10.1080 / 0034340042000280965$

Fritsch, M., \& Mueller, P. (2005). How persistent are regional start-up rates? An empirical analysis. Research of Technological Innovation and Management Policy, 9, 71-82.

Fritsch, M., \& Wyrwich, M. (2014). The Long Persistence of Regional Levels of Entrepreneurship: Germany, 1925-2005. Regional Studies, 48(6), 955-973. doi: 10.1080/00343404.2013.816414

Garnsey, E., \& Heffernan, P. (2005). High-technology clustering through spin-out and attraction: the Cambridge case. Regional Studies, 39(8), 1127-1144. doi: 10.1080/00343400500328289

Gertler, M., \& Levitte, Y. (2005). Local nodes in global networks: The geography of knowledge flows in biotechnology innovation. Industry and Innovation, 12(4), 487507. doi: 10.1080/13662710500361981

Ghio, N., Guerini, M., Lehmann, E. E., \& Rossi-Lamastra, C. (2014). The emergence of the knowledge spillover theory of entrepreneurship. Small Business Economics, doi 10.1007/s11187-014-9588-y. 
Giuliani, E. (2005). Cluster absorptive capacity: Why do some clusters forge ahead and others lag behind? European Urban and Regional Studies, 12(3), 269-288. doi: 10.1177/0969776405056593

Glaeser, E. L. (2002). Learning in Cities. Journal of Urban Economics, 46(2), 254-277. doi: 10.1006/juec.1998.2121

Glaeser, E. L., Kallal, H. D., Scheinkman, J. A., \& Shleifer, A. (1992) Growth in cities. Journal of Political Economy, 100(6), 1126-1152.

Goerzen, A. (2005). Managing alliance networks: Emerging practices of multinational corporations. Academy of Management Executive, 19(2), 94-107. doi: 10.5465/AME.2005.16965102

Goerzen, A., \& Beamish, P. W. (2005). The effect of alliance network diversity on multinational enterprise performance. Strategic Management Journal, 26(4), 333-354. doi: $10.1002 / \mathrm{smj} .447$

Grant, R. (1996). Toward a knowledge-based theory of the firm. Strategic Management Journal, 17(S2), 109-122. doi: 10.1002/smj.4250171110

Grant, R., \& Baden-Fuller, C. (2004). A knowledge accessing theory of strategic alliances. Journal of Management Studies, 41(1), 61-84. doi: 10.1111/j.14676486.2004.00421.x

Greve, A., \& Salaff, J. W. (2003). Social networks and entrepreneurship. Entrepreneurship Theory and Practice, 28(1), 1-22. doi: 10.1111/1540-8520.00029

Griliches, Z. (1979). Issues in Assessing the Contribution of R\&D to Productivity Growth. Bell Journal of Economics, 10(1), 92-116. doi: 10.2307/3003321

Grossman, G. M., \& Helpman, E. (1994). Endogenous innovation in the theory of growth. Journal of Economic Perspectives, 8(1), 23-44.

Gulati, R. (1999). Network location and learning: the influence of network resources and firm capabilities on alliance formation. Strategic Management Journal, 20(5), 397-420. doi: 10.1002/(SICI)1097-0266(199905)20:5<397::AID-SMJ35>3.0.CO;2-K

Gulati, R. (2007). Managing Network Resources: Alliances, Affiliations, and Other Relational Assets. Oxford: Oxford University Press.

Gulati, R., \& Gargiulo, M. (1999). Where do interorganizational networks come from? American Journal of Sociology, 104(5), 1439-1493. doi: 10.1086/210179

Gulati, R., Nohira, N., \& Zaheer, A. (2000). Strategic networks. Strategic Management Journal, 21(3), 203-215. doi: 10.1002/(SICI)1097-0266(200003)21:3<203::AIDSMJ102>3.0.CO;2-K

Ha, J., \& Howitt, P. (2007). Accounting for trends in productivity and R\&D: a Schumpeterian critique of semi-endogenous growth theory. Journal of Money, Credit and Banking, 39(4), 913-951. doi: 10.1111/j.1538-4616.2007.00045.x

Harris, R. G. (2001). The knowledge-based economy: intellectual origins and new economic perspectives. International Journal of Management Reviews, 3(1), 21-40. doi: 10.1111/1468-2370.00052

Harris, R. G. (2011). Models of regional growth: Past, present and future. Journal of Economic Surveys, 25(5), 913-951. doi: 10.1111/j.1467-6419.2010.00630.x

Hauser, C., Tappeiner, G., \& Walde, J. (2007). The learning region: the impact of social capital and weak ties on innovation. Regional Studies, 41(1), 75-88. doi: $10.1080 / 00343400600928368$

Hayter, C. (2013). Conceptualizing knowledge-based entrepreneurship networks: Perspectives from the literature. Small Business Economics, 41(4), 899-911. doi: 10.1007/s11187-013-9512-x 
Hipp, C., \& Grupp, H. (2005). Innovation in the service sector: The demand for servicespecific innovation measurement concepts and typologies. Research Policy, 34(4), 517-535. doi: 10.1016/j.respol.2005.03.002

Hitchens, D. M. W. N., O’Farrell, P. N., \& Conway, C. D. (1996). The competitiveness of business services in the Republic of Ireland, Northern Ireland, Wales, and the South East of England. Environment and Planning A, 28(7), 1299-1313. doi: 10.1068/a281299

Hite, J., \& Hesterly, W. S. (2001). The evolution of firm networks: from emergence to early growth of the firm. Strategic Management Journal, 22(3), 275-286. doi: 10.1002/smj.156

Howells, J. (2012). The geography of knowledge: never so close but never so far apart. Journal of Economic Geography, 12(5), 1003-1020. doi: 10.1093/jeg/lbs027

Huber, F. (2012). Do clusters really matter for innovation practices in Information Technology? Questioning the significance of technological knowledge spillovers. Journal of Economic Geography, 12(1), 107-126. doi: 10.1093/jeg/lbq058

Huggins, R. (2010). Forms of network resource: Knowledge access and the role of inter-firm networks. International Journal of Management Reviews, 12(3), 335-352 doi: 10.1111/j.1468-2370.2009.00266.x

Huggins, R., \& Izushi, H. (2007). Competing for Knowledge: Creating, Connecting and Growing. London: Routledge.

Huggins, R., \& Johnston, A. (2009). Knowledge networks in an uncompetitive region: SME innovation and growth. Growth and Change, 40(2), 227-259. doi: 10.1111/j.14682257.2009.00474.X

Huggins, R., \& Johnston, A. (2010). Knowledge flow and inter-firm networks: The influence of network resources, spatial proximity, and firm size. Entrepreneurship and Regional Development, 22(5), 457-484. doi: 10.1080/08985620903171350

Huggins, R., \& Thompson, P. (2014). A Network-based view of regional growth. Journal of Economic Geography, 14(3), 511-545. doi:10.1093/jeg/lbt012

Huggins, R., \& Weir, M. (2007). Intellectual assets and public policy. Journal of Intellectual Capital, 8(4), 708-720. doi: 10.1108/14691930710830855

Huggins, R., \& Williams, N. (2009). Enterprise and public policy: a review of Labour government intervention in the United Kingdom. Environment and Planning $C$ : Government and Policy, 27(1), 19-41. doi: 10.1068/c0762b

Huggins R., \& Williams, N. (2011). Entrepreneurship and regional competitiveness: The role and progression of policy. Entrepreneurship and Regional Development, 23(9-10), 907-932. doi: 10.1080/08985626.2011.577818

Huggins, R., Morgan, B., \& Williams, N. (2014). Regions as Enterprising Places: Governance, Policy and Development. In L. Pugalis, \& J. Liddle (Ed.), Enterprising Places: Leadership and Governance Networks (Contemporary Issues in Entrepreneurship Research, Volume 3) (pp.1-28). Bingley: Emerald Group Publishing Limited.

Huggins, R., Johnston, A., \& Thompson, P. (2012). Network capital, social capital, and knowledge flow: How the nature of inter-organisational networks impacts on innovation. Industry and Innovation, 19(3), 203-232. doi: 10.1080/13662716.2012.669615

Huggins, R., Izushi, H., Clifton, N., Jenkins, S., Prokop, D., \& Whitfield, C. (2010). Sourcing Knowledge for Innovation: The International Dimension. London: NESTA.

Ibert, O. (2007). Towards a geography of knowledge creation: The ambivalences between 'knowledge as an object' and 'knowing in practice'. Regional Studies, 41(1), 103-114. doi: 10.1080/00343400601120346 
Ikeda, S. (2008). The meaning of 'social capital' as it relates to the market process. Review of Austrian Economics, 21(2/3), 167-182. doi: 10.1007/s11138-007-0037-x

Ireland, R. D., Hitt, M. A., \& Vaidyanath, D. (2002). Alliance management as a source of competitive advantage. Journal of Management, 28(3), 413-446. doi: $10.1177 / 014920630202800308$

Iyer, S., Kitson, M., \& Toh, B. (2005). Social capital, economic growth and regional development. Regional Studies, 39(8), 1015-1040. doi: 10.1080/00343400500327943

Izushi, H. (1997). Conflict between two industrial networks: technological adaptation and interfirm relationships in the ceramics industry in Seto, Japan. Regional Studies, 31(2), 117-129. doi: 10.1080/00343409750133242

Jack, S. L. (2005). The role, use and activation of strong and weak network ties: A qualitative analysis. Journal of Management Studies, 42(6), 1233-1259. doi: 10.1111/j.14676486.2005.00540.x

Jack, S., Dodd, S. D., \& Anderson, A. (2008). Change and the development of entrepreneurial networks over time: A processual perspective. Entrepreneurship and Regional Development, 20(2), 125-159. doi: 10.1080/08985620701645027

Jack, S., Moult, S., Anderson, A. R., \& Dodd, S. (2010). An entrepreneurial network evolving: Patterns of change. International Small Business Journal, 28(4), 315-337. doi: 10.1177/0266242610363525

Jaffe, A. B., Trajtenberg, M., \& Henderson, R. (1993). Geographic localization of knowledge spillovers as evidenced by patent citations. Quarterly journal of Economics, 108(3), 577-598.

Jensen, M. B., Johnson, B., Lorenz, E., \& Lundvall, B. A. (2007). Forms of knowledge and modes of innovation. Research Policy, 36(5), 680-693. doi: 10.1016/j.respol.2007.01.006

Johannisson, B., Ramírez-Pasillas, M., \& Karlsson, G. (2002). The institutional embeddedness of local inter-firm networks: A leverage for business creation. Entrepreneurship and Regional Development, 14(4), 297-315. doi: 10.1080/08985620210142020

Keeble, D. (1997). Small firms, innovation and regional development in Britain in the 1990s. Regional Studies, 31(3), 281-293. doi: 10.1080/00343409750134692

Kim, T-Y., Oh, H., \& Swaminathan, A. (2006). Framing interorganizational network change: a network inertia perspective. Academy of Management Review, 31(3), 704-720. doi: 10.5465/AMR.2006.21318926

Kirzner, I. M. (1973). Competition and entrepreneurship. Chicago, IL: University of Chicago Press.

Klepper, S. (1997). Industry life cycles. Industrial and Corporate Change, 6(1), 145-181. doi: 10.1093/icc/6.1.145

Knoben, J., \& Oerlemans, L. A. G. (2006). Proximity and inter-organizational collaboration. International Journal of Management Reviews, 8(2), 71-89. doi: 10.1111/j.14682370.2006.00121.x

Kodama, F. (1992). Technology Fusion and the New R\&D. Harvard Business Review, 70(4), 70-78.

Kogut, B. (2000). The network as knowledge: generative rules and the emergence of structure. Strategic Management Journal, 21(3), 405-425. doi: 10.1002/(SICI)10970266(200003)21:3<405::AID-SMJ103>3.0.CO;2-5

Krackhardt, D. (1994). Constraints on the interactive organization as an ideal type. In C. Heckscher, \& A. Donnellon (Eds.), The Post-Bureaucratic Organization: New Perspectives on Organizational Change (pp. 211-222). Thousand Oaks, CA: Sage. 
Kramera, J-P., \& Revilla Diez, J. (2012). Catching the local buzz by embedding? Empirical insights on the regional embeddedness of multinational enterprises in Germany and the UK. Regional Studies, 46(10), 1303-1317. doi: 10.1080/00343404.2011.571240.

Kramera, J-P., Marinelli, E., Iammarino, S., \& Revilla Diez, J. (2011). Intangible assets as drivers of innovation: Empirical evidence on multinational enterprises in German and UK regional systems of innovation. Technovation, 31(9), 447-458. doi:10.1016/j.technovation.2011.06.005

Krätke, S. (2010). Regional knowledge networks: A network analysis approach to the interlinking of knowledge resources. European Urban and Regional Studies, 17(1), 83-97. doi: 10.1177/0969776409350794

Krugman, P. (2005). Second winds for industrial regions? In D. Coyle et al (Eds.), New Wealth for Old Nations: Scotland's Economic Prospects (pp. 35-47). Princeton University Press, Princeton.

Labianca, G., \& Brass, D. J. (2006). Exploring the social ledger: negative relationships and negative asymmetry in social networks in organizations. Academy of Management Review, 31(3), 596-614. doi: 10.5465/AMR.2006.21318920

Larson, A. (1992). Network dyads in entrepreneurial settings: A study of the governance of exchange relationships. American Science Quarterly, 37(1), 76-104. doi: $10.2307 / 2393534$

Laursen, K., \& Salter, A. (2006). Open for innovation: the role of openness in explaining innovation performance among U.K. manufacturing firms. Strategic Management Journal, 27(2), 131-150. doi: 10.1002/smj.507

Lavie, D. (2006). The competitive advantage of interconnected firms: an extension of the resource-based view. Academy of Management Review, 31(3), 638-658. doi: 10.5465/AMR.2006.21318922

Lawton Smith, H., Romeo, S., \& Virahsawmy, M. (2012). Business and professional networks: scope and outcomes in Oxfordshire. Environment and Planning A, 44(8), 1801 - 1818. doi:10.1068/a44461

Lechner, C., \& Dowling, M. (2003). Firm networks: external relationships as sources for the growth and competitiveness of entrepreneurial firms. Entrepreneurship and Regional Development, 15(1), 1-26. doi: 10.1080/08985620210159220

Lee, S. Y., Florida, R., \& Acs, Z. J. (2004). Creativity and entrepreneurship: A regional analysis of new firm formation. Regional Studies, 38(8), 879-891. doi: 10.1080/0034340042000280910

Lichtenthaler, U. (2005). External commercialization of knowledge: review and research agenda. International Journal of Management Reviews, 7(4), 231-255. doi: 10.1111/j.1468-2370.2005.00115.x

Linder, I., \& Strulik, H. (2014). From tradition to modernity economic growth in a small world. Journal of Development Economics, 109, 17-29. doi: 10.1016/j.jdeveco.2014.03.006

Lissoni, F. (2001). Knowledge codification and the geography of innovation: the case of Brescia mechanical cluster. Research Policy, 30(9), 1479-1500. doi: 10.1016/S00487333(01)00163-9

Lorentzen, A. (2008). Knowledge networks in local and global space. Entrepreneurship and Regional Development, 20(6), 533-545. doi: 10.1080/08985620802462124

Lorenzen, M. (2007). Social capital and localised learning: proximity and place in technological and institutional dynamics. Urban Studies, 44(4), 799-817. doi: 10.1080/00420980601184752 
Lorenzoni, G., \& Lipparini, A. (1999). The leverage of interfirm relationships as a distinctive organizational capability: a longitudinal study. Strategic Management Journal, 20(4), 317-338. doi: 10.1002/(SICI)1097-0266(199904)20:4<317::AID-SMJ28>3.0.CO;2-3

Lucas, R. E. (1988). On the mechanics of economic development. Journal of Monetary Economics, 22(1), 3-42. doi: 10.1016/0304-3932(88)90168-7

Lundvall, B.-Å. (ed) (1995). National Systems of Innovation: Towards a Theory of Innovation and Interactive Learning. London: Pinter.

Macpherson, A., \& Holt, R. (2007). Knowledge, learning and small firm growth: A systematic review of the evidence. Research Policy, 36(2), 172-192. doi:10.1016/j.respol.2006.10.001

Madhavan, R., Koka, B., \& Prescott, J. E. (1998). Networks in transition: how industry events (re)shape interfirm relationships. Strategic Management Journal, 19(5), 439459. doi: 10.1002/(SICI)1097-0266(199805)19:5<439::AID-DIA952>3.0.CO;2-2

Mahroum, S., Huggins, R., Clayton, N., Pain, K., \& Taylor, P. (2008). Innovation by Adoption: Measuring and Mapping Absorptive Capacity in UK Nations and Regions. London: NESTA.

Malecki, E. J. (2007). Cities and regions competing in the global economy: knowledge and local development policies. Environment and Planning C: Government and Policy, 25(5), 638-654. doi: 10.1068/c0645

Malecki, E. J. (2010). Everywhere? The geography of knowledge. Journal of Regional Science, 50(1), 493-513. doi: 10.1111/j.1467-9787.2009.00640.x

March, J. G. (1991). Exploration and exploitation in organizational learning. Organization Science, 2(1), 71-87.

Marr, B., Schiuma, G., \& Neely, A. (2004). The dynamics of value creation: mapping your intellectual performance drivers. Journal of Intellectual Capital, 5(2), 312-325. doi: $10.1108 / 14691930410533722$

Martin, R., \& Sunley, P. J. (2003). Deconstructing Clusters: Chaotic Concept or Policy Panacea? Journal of Economic Geography, 3(1), 5-35. doi: 10.1093/jeg/3.1.5

Martin, R., \& Sunley, P. (2007). Complexity thinking and evolutionary economic geography. Journal of Economic Geography, 7(5), 573-601. doi: 10.1093/jeg/lbm019

Maskell, P. (2000). Social capital, innovation, and competitiveness. In S. Baron, J. Field, \& T. Schuller (Eds.), Social Capital: Critical Perspectives (pp. 111-123). Oxford: Oxford University Press.

Maskell, P., Bathelt, H., \& Malmberg, A. (2006). Building global knowledge pipelines: The role of temporary clusters. European Planning Studies, 14(8), 997-1013. doi: $10.1080 / 09654310600852332$

Mattes, J. (2012). Dimensions of proximity and knowledge bases: innovation between spatial and non-spatial factors. Regional Studies, 46(8), 1085-1099. doi: 10.1080/00343404.2011.552493

Maurer, I., \& Ebers, M. (2006). Dynamics of social capital and their performance implications: lessons from biotechnology start-ups. Administrative Science Quarterly, 51(2), 262-292. doi: 10.2189/asqu.51.2.262

McDougall, P. P., \& Oviatt, B. M. (2000). International entrepreneurship: the intersection of two research paths. Academy of Management Journal, 43(5), 902-906. doi: $10.2307 / 1556418$

McEvily, B., \& Zaheer, A. (1999). Bridging ties: a source of firm heterogeneity in competitive capabilities. Strategic Management Journal, 20(12), 1133-1156. doi: 10.1002/(SICI)1097-0266(199912)20:12<1133::AID-SMJ74>3.0.CO;2-7 
McFadyen, M. A., \& Cannella, A. A. (2004). Social capital and knowledge creation: diminishing returns of the number and strength of exchange relationships. Academy of Management Journal, 47(5), 735-746. doi: 10.2307/20159615

Meagher, K., \& Rogers, M. (2004). Network density and R\&D spillovers. Journal of Economic Behavior and Organization, 53(2), 237-260. doi: 10.1016/j.jebo.2002.10.004

Molina-Morales, F. X., \& Martínez-Fernández, M. T. (2009). Too much love in the neighborhood can hurt: how an excess of intensity and trust in relationships may produce negative effects on firms. Strategic Management Journal, 30(9), 1013-1023. doi: $10.1002 / \mathrm{smj} .766$

Monge, P. M., \& Contractor, N. S. (2003). Theories of Communication Networks. New York, NY: Oxford University Press.

Mowery, D., Oxley, J., \& Silverman, B. (1996). Strategic alliances and interfirm knowledge transfer. Strategic Management Journal, 17(S2), 77-91. doi: 10.1002/smj.4250171108

Mueller, P. (2006). Entrepreneurship in the region: Breeding ground for nascent entrepreneurs? Small Business Economics, 27(1), 41-58. doi: 10.1007/s11187-0066951-7

Mueller P., Van Stel A., \& Storey D. J. (2008). The effects of new firm formation on regional development over time: the case of Great Britain. Small Business Economics, 30(1), 59-71. doi: 10.1007/s11187-007-9056-z

Nauwelaers, C., \& Wintjes, R. (2003). Towards a new paradigm for innovation policy? In B. Asheim, A. Isaksen, C. Nauwelaers, \& F. Tödtling (Eds), Regional Innovation Policy for Small-Medium Enterprises (pp.193-219). Cheltenham: Edward Elgar.

Nelson, R. R., \& Winter, S. G. (1982). An Evolutionary Theory of Economic Change. Cambridge MA: Belknap Press.

Nonaka, I., \& Takeuchi, H. (1995). The Knowledge-Creating Company: How Japanese Companies Create the Dynamics of Innovation. Oxford: Oxford University Press.

Obstfeld, D. (2005). Social networks, the tertius iungens orientation, and involvement in innovation. Administrative Science Quarterly, 50(1), 100-130. doi: 10.2189/asqu.2005.50.1.100

Oviatt, B. M., \& McDougall, P. P. (2005). Defining international entrepreneurship and modeling the speed of internationalization. Entrepreneurship Theory and Practice, 29(5), 537-554. doi: 10.1111/j.1540-6520.2005.00097.x

Ozman, M. (2009). Inter-firm networks and innovation: a survey of literature. Economics of Innovation and New Technology, 18(1), 39-67. doi: 10.1080/10438590701660095

Palazzo, G. (2005). Postnational constellations of innovativeness: A cosmopolitan approach. Technology Analysis \& Strategic Management, 17(1), 55-72. doi: 10.1080/09537320500044552

Perkmann, M., \& Walsh, K. (2007). University-industry relationships and open innovation: Towards a research agenda. International Journal of Management Reviews, 9(4), 259-280. doi: 10.1111/j.1468-2370.2007.00225.x

Pittaway, L., Roberston, M., Munir, K., Denyer, D., \& Neely, A. (2004). Networking and innovation: a systematic review of the evidence. International Journal of Management Reviews, 5(3/4), 137-168. doi: 10.1111/j.1460-8545.2004.00101.x

Podolny, J. M., \& Page, K. L. (1998). Network forms of organization. Annual Review of Sociology, 24, 57-76.

Porter, M. E. (1990). The Competitive Advantage of Nations. New York, NY: Free Press. 
Porter, M. E. (2000). Location, Competition, and Economic Development: Local Clusters in a Global Economy. Economic Development Quarterly, 14(1), 15-34. doi: 10.1177/089124240001400105

Porter, M. E. (2003). The Economic Performance of Regions. Regional Studies, 37(6), 545546. doi: 10.1080/0034340032000108688

Powell, B. (2007). Making Poor Nations Rich: Entrepreneurship and the Process of Economic Development. Stanford University Press, Stanford.

Powell, W. W., \& Grodal, S. (2005). Networks of innovators. In J. Fagerberg, D. C. Mowery, \& R. R. Nelson (Eds.), The Oxford Handbook of Innovation (pp. 56-85). Oxford: Oxford University Press.

Powell, W. W., Koput, K. W., \& Smith-Doerr, L. (1996). Interorganizational collaboration and the locus of innovation: Networks of learning in biotechnology. Administrative Science Quarterly, 41, 116-145. doi: 10.2307/2393988

Power, D., \& Jansson, J. (2008). Cyclical clusters in global circuits: Overlapping spaces in furniture trade fairs. Economic Geography, 84(4), 423-448. doi: 10.1111/j.19448287.2008.00003.x

Presutti, M., Boari, C., \& Majocchi, A. (2013). Interorganizational geographical proximity and local start-ups' knowledge acquisition: a contingency approach. Entrepreneurship and Regional Development, 25(5/6), 446-467. doi:10.1080/08985626.2012.760003.

Qian, H., Acs, Z. J., \& Stough, R. R. (2013). Regional systems of entrepreneurship: the nexus of human capital, knowledge and new firm formation. Journal of Economic Geography, 13(4), 559-587. doi:10.1093/jeg/lbs009.

Quatraro, F. (2010). Knowledge coherence, variety and economic growth: Manufacturing evidence from Italian regions. Research Policy, 39(10), 1289-1302. doi: 10.1016/j.respol.2010.09.005

Reynolds, P. D., Camp, S. M., Bygrave, W. D., Autio, E., \& Hay, M. (2001). Global Entrepreneurship Monitor: 2001 Executive Report. Kauffman Centre for Entrepreneurial Leadership at the Ewing Marion Kauffman Foundation.

Reynolds, P. D., Bygrave, W. D., Autio, E., Cox, L. W., \& Hay, M. (2002). Global Entrepreneurship Monitor: 2002 Executive Report. Kansas City, MO: Ewing Marion Kauffman Foundation.

Rinallo, D., \& Golfetto, F. (2011). Exploring the knowledge strategies of temporary cluster organizers: A longitudinal study of the EU fabric industry trade shows (1986-2006). Economic Geography, 87(4), 453-476. doi: 10.1111/j.1944-8287.2011.01127.x

Roberts, M., \& Setterfield, M. (2010). Endogenous regional growth: A critical survey. In M. Setterfield (Ed.), Handbook of Alternative Theories of Economic Growth (pp. 431450). Cheltenham: Edward Elgar.

Rodríguez-Pose, A., \& Crescenzi, R. (2008). Research and development, spillovers, innovation systems, and the genesis of regional growth in Europe. Regional Studies, 42(1), 51-67. doi: 10.1080/00343400701654186

Rogers, M. (2004). Networks, firm size and innovation. Small Business Economics, 22(2), 141-153. doi: 10.1023/B:SBEJ.0000014451.99047.69

Romer, P. M. (1986). Increasing returns and long-run growth. Journal of Political Economy, 94(5), 1002-1037.

Romer, P. M. (1990). Endogenous technological change. Journal of Political Economy, 98(5), 71-102.

Romer, P. M. (1996). Why, indeed, in America? Theory, history. and the origins of modern economic growth. American Economic Review, 86(2), 202-206.

Romer, P. M. (2007). Economic growth. In D. Henderson (Ed.), The Concise Encyclopedia of Economics

(pp.

Indianapolis:

Liberty

Fund. 
http://www.econlib.org/library/Enc/Economic-Growth.html Accessed 4 December 2014

Rychen, F., \& Zimmermann, J. B. (2008). Clusters in the global knowledge-based economy: knowledge gatekeepers and temporary proximity. Regional Studies, 42(6), 767-776. doi: 10.1080/00343400802088300

Sammarra, A., \& Biggiero, L. (2008). Heterogeneity and specificity of inter-firm knowledge flows in innovation networks. Journal of Management Studies, 45, 800-829.

Sautet, F., \& Kirzner, I. (2006). The Nature and Role of Entrepreneurship in Markets: Implications for Policy. Policy Primer No. 4, Mercatus Policy Series, Washington, DC: George Mason University.

Saxenian, A. (2005). From brain drain to brain circulation: transnational communities and regional upgrading in India and China. Studies in Comparative International Development, 40(2), 35-61. doi: 10.1007/BF02686293

Schuldt, N., \& Bathelt, H. (2011). International trade fairs and global buzz. Part II: Practices of global buzz. European Planning Studies, 19(1), 1-22. doi: 10.1080/09654313.2011.530390

Schumpeter, J. A. (1934). The Theory of Economic Development. Cambridge MA: Harvard University Press.

Schumpeter, J. A. (1942). Capitalism, socialism and democracy. London: Routledge.

Schutjens, V., \& Stam, E. (2003). The evolution and nature of young firm networks: A longitudinal perspective. Small Business Economics, 21(2), 115-134. doi: 10.1023/A:1025093611364

Scott, A. (1995). The geographic foundations of industrial performance. Competition and Change, 1(1), 51-66.

Scott, A., \& Storper, M. (2003). Regions, Globalization, Development. Regional Studies, 37(6-7), 549-578. doi: 10.1080/0034340032000108697

Sleuwaegen, L., \& Boiardi, P. (2014). Creativity and regional innovation: Evidence from EU regions. Research Policy, 43(9), 1508-1522. doi: 10.1016/j.respol.2014.03.014.

Sobel, R. S., Clark, J. R., \& Lee, D. R. (2007). Freedom, barriers to entry, entrepreneurship, and economic progress. The Review of Austrian Economics, 20(4), 221-236. doi: 10.1007/s11138-007-0023-3

Stam, E. (2010). Entrepreneurship, Evolution and Geography. In R. Boschma, \& R. Martin (Eds.), The Handbook of Evolutionary Economic Geography (pp. 139-161). Cheltenham: Edward Elgar.

Stewart, T. A. (1997). Intellectual Capital: The New Wealth of Organizations. New York, NY: Doubleday-Currency.

Storper, M. (1997). The Regional World: Territorial Development in a Global Economy. New York, NY: Guilford Press.

Storper, M. (2010). Why does a city grow? Specialisation, human capital or institutions? Urban Studies, 47(10), 2027-2050. doi: 10.1177/0042098009359957

Storper, M., \& Scott, A. J. (2009). Rethinking human capital, creativity and urban growth. Journal of Economic Geography, 9(2), 147-167. doi: 10.1093/jeg/lbn052

Storper, M., \& Venables, A. J. (2004). Buzz: face-to-face contact and the urban economy. Journal of Economic Geography, 4(4), 351-370. doi: 10.1093/jnlecg/lbh027

Stuart, T. E. (2000). Interorganizational alliances and the performance of firms: a study of growth and innovation rates in a high-technology industry. Strategic Management Journal, 21(8), 791-811. doi: 10.1002/1097-0266(200008)21:8<791::AIDSMJ121>3.0.CO;2-K

Tappeiner, G., Hauser, C., \& Walde, J. (2008). Regional knowledge spillovers: Fact or artifact? Research Policy, 37(5), 861-874. doi: 10.1016/j.respol.2007.07.013 
Teece, D. J. (1998). Capturing value from knowledge assets: the new economy, markets for know-how, and intangible assets. California Management Review, 40(3), 55-79.

Teixeira, A., Santos, P., \& Oliveira Brochado, A. (2006). 'Does proximity really matter in international R\&D cooperative projects?', Paper presented at the European Network on Industrial Policy (EUNIP) 9th International Conference, June 20-22, in Limerick, Ireland.

Ter Wal, A., \& Boschma, R. (2011). Co-evolution of firms, industries and networks in space. Regional Studies, 45(7), 919-933. doi: 10.1080/00343400802662658

Tomlinson, P. (2010). Co-operative ties and innovation: Some new evidence for UK manufacturing. Research Policy, 39(6), 762-775. doi: 10.1016/j.respol.2010.02.010

Torré, A. (2008). On the role played by temporary geographical proximity in knowledge transmission. Regional Studies, 42(6), 869-889. doi: 10.1080/00343400801922814

Tura, T., \& Harmaakorpi, V. (2005). Social capital in building regional innovation capability. Regional Studies, 39(8), 1111-1125. doi: 10.1080/00343400500328255

Tushman, M. L., \& Katz, R. (1980). External communication and project performance: An investigation into the role of gatekeepers. Management Science, 26(11), 1071-1085. doi: 10.1287/mnsc.26.11.1071

Utterback, J. M., \& Abernathy, W. J. (1975). A dynamic model of process and product innovation. Omega, 3(6), 639-656. doi: 10.1016/0305-0483(75)90068-7

van Geenhuizen, M. (2008). Knowledge networks of young innovators in the urban economy: biotechnology as a case study. Entrepreneurship and Regional Development, 20(2), 161-183. doi: 10.1080/08985620701748318

Vaz, T. D., \& Nijkamp, P. (2009). Knowledge and innovation: The strings between global and local dimensions of sustainable growth. Entrepreneurship and Regional Development, 21(4), 441-455. doi: 10.1080/08985620903020094

von Hippel, E. (2005). Democratizing innovation. Cambridge, MA: MIT Press.

Vorley, T., Mould, O., \& Courtney, R. (2012). My networking is not working! Conceptualizing the latent and dysfunctional dimensions of the network paradigm. Economic Geography, 88(1), 77-96. doi: 10.1111/j.1944-8287.2011.01141.x

Walter, J., Lechner, C., \& Kellermanns, F. W. (2007). Knowledge transfer between and within alliance partners: private versus collective benefits of social capital. Journal of Business Research, 60(7), 698-710. doi: 10.1016/j.jbusres.2007.01.026

Werker, C., \& Athreye, S. (2004). Marshall's disciples: knowledge and innovation driving regional economic development and growth. Journal of Evolutionary Economics, 14(5), 505-523. doi: 10.1007/s00191-004-0237-5

Westlund, H. (1999). An interaction-cost perspective on networks and territory. Annals of Regional Science, 33(1), 93-121. doi: 10.1007/s001680050094

Weterings, A., \& Ponds, R. (2009). Do regional and non-regional knowledge flows differ? An empirical study on clustered firms in the Dutch life sciences and computing services industry. Industry and Innovation, 16(1), 11-31. doi: 10.1080/13662710902728035

Williamson, O. E. (1993). Calculativeness, trust, and economic organization. Journal of Law and Economics, 36(1), 453-486.

Wolfe, D., \& Gertler, M. (2004). Clusters from the inside and out: local dynamics and global linkages. Urban Studies, 41(5/6), 1071-1093. doi: 10.1080/00420980410001675832

Yli-Renko, H., Autio, E., \& Sapienza, H. J. (2001). Social capital, knowledge acquisition, and knowledge exploitation in young technology-based firms. Strategic Management Journal, 22(6/7), 587-613. doi: 10.1002/smj.183 
Zaheer, A., \& Bell, G. (2005). Benefiting from network position: firm capabilities, structural holes, and performance. Strategic Management Journal, 26(9), 809-825. doi: 10.1002/smj.482

Zahra, S. A., \& George, G. (2002). Absorptive capacity: a review, reconceptualization, and extension. Academy of Management Review, 27(2), 185-203. doi: 10.5465/AMR.2002.6587995

Zucker, L. G., Darby, M. R., Furner, J., Liu, R. C., \& Hongyan, M. (2007). Minerva unbound: Knowledge stocks, knowledge flows and new knowledge production. Research Policy, 36(6), 850-863. doi: 10.1016/j.respol.2007.02.007 
Table 1: Implications of a Network Theory of Entrepreneurship, Innovation and Regional Growth

\begin{tabular}{|c|c|c|c|c|}
\hline & Proposition & Theoretical Implications & Entrepreneurial Implications & Public Policy Implications \\
\hline 1 & $\begin{array}{l}\text { Regions with higher rates of } \\
\text { entrepreneurship and network } \\
\text { capital accumulation by } \\
\text { entrepreneurial firms will } \\
\text { experience higher rates of } \\
\text { innovation. }\end{array}$ & $\begin{array}{l}\text { The interaction between rates of } \\
\text { entrepreneurship and network } \\
\text { capital should be more explicitly } \\
\text { integrated into endogenous } \\
\text { models of regional growth. }\end{array}$ & $\begin{array}{l}\text { Entrepreneurial success in } \\
\text { generating innovation is likely to } \\
\text { be partly governed by the } \\
\text { regional environment in which } \\
\text { entrepreneurial firms are located. }\end{array}$ & $\begin{array}{l}\text { In less innovative and developed } \\
\text { regions, entrepreneurial firms are } \\
\text { likely to require support to } \\
\text { generate the most appropriate and } \\
\text { effective networks. }\end{array}$ \\
\hline 2 & $\begin{array}{l}\text { Entrepreneurial firms with a } \\
\text { greater capacity to accumulate } \\
\text { network capital will achieve } \\
\text { higher rates innovation. }\end{array}$ & $\begin{array}{l}\text { Network theories of firm level } \\
\text { differences in rates of innovation } \\
\text { should seek to conceptualise } \\
\text { inter-firm and inter-organisational } \\
\text { networks as a form of capital } \\
\text { asset that allows access to } \\
\text { external knowledge resources. }\end{array}$ & $\begin{array}{l}\text { Innovation-seeking entrepreneurs } \\
\text { should incentivise the } \\
\text { accumulation of network capital } \\
\text { within their firm }\end{array}$ & $\begin{array}{l}\text { Ensure the necessary support to } \\
\text { help firms develop their } \\
\text { capability to establish effective } \\
\text { networks is in place. }\end{array}$ \\
\hline 3 & $\begin{array}{l}\text { Entrepreneurial firms with a } \\
\text { greater capacity to accumulate } \\
\text { network capital will improve the } \\
\text { permeability of the knowledge } \\
\text { filter. }\end{array}$ & $\begin{array}{l}\text { The Knowledge Spillover Theory } \\
\text { of Entrepreneurship should be } \\
\text { extended to account further for } \\
\text { the networks entrepreneurs and } \\
\text { their firms are required to } \\
\text { establish to access external } \\
\text { knowledge. }\end{array}$ & $\begin{array}{l}\text { Entrepreneurs incentivising the } \\
\text { accumulation of network capital } \\
\text { are likely to have better access to } \\
\text { economically beneficial and } \\
\text { commercialisable knowledge. }\end{array}$ & $\begin{array}{l}\text { Ensure that firms are capable of } \\
\text { accessing the most appropriate } \\
\text { and suitable knowledge for their } \\
\text { innovation needs. }\end{array}$ \\
\hline 4 & $\begin{array}{l}\text { Entrepreneurial firms with a } \\
\text { greater capacity to access } \\
\text { superior, excludable and miscible } \\
\text { forms of knowledge will achieve } \\
\text { higher rates of innovation. }\end{array}$ & $\begin{array}{l}\text { Network theories of firm level } \\
\text { differences in rates of innovation } \\
\text { should seek to account further for } \\
\text { differences in the quality of the } \\
\text { knowledge accessed from } \\
\text { external sources. }\end{array}$ & $\begin{array}{l}\text { Entrepreneurs need to be aware of } \\
\text { the potential trade-offs between } \\
\text { accessing knowledge that is } \\
\text { relatively easy to source and } \\
\text { absorb, and that which may be } \\
\text { more difficult to identify and } \\
\text { integrate but potentially offers far } \\
\text { greater economic returns. }\end{array}$ & $\begin{array}{l}\text { Ensure that firms have the } \\
\text { necessary human capital and } \\
\text { absorptive capacity to access } \\
\text { knowledge of the highest quality. }\end{array}$ \\
\hline 5 & Entrepreneurial firms with a & Theories of strategic & Entrepreneurs need to ensure & Provide support to firms with \\
\hline
\end{tabular}




\begin{tabular}{|l|l|l|l|l|} 
& $\begin{array}{l}\text { greater capacity to manage } \\
\text { inbound and outbound flows of } \\
\text { knowledge will be more effective } \\
\text { in accessing superior, excludable } \\
\text { and miscible forms of knowledge. }\end{array}$ & $\begin{array}{l}\text { entrepreneurial management need } \\
\text { to ensure that the role of network } \\
\text { management is embedded within } \\
\text { future conceptual frameworks. }\end{array}$ & $\begin{array}{l}\text { management systems are in place } \\
\text { to effectively search, screen and } \\
\text { select the most appropriate } \\
\text { knowledge to flow in and out of } \\
\text { their firms. }\end{array}$ & $\begin{array}{l}\text { regard to the effective } \\
\text { 'gatekeeping' of their knowledge. }\end{array}$ \\
\hline 6 & $\begin{array}{l}\text { Entrepreneurial firms with a } \\
\text { greater capacity to access high } \\
\text { quality knowledge through } \\
\text { selected routes and channels } \\
\text { regardless of the geographic } \\
\text { location of knowledge sources } \\
\text { will achieve higher rates of } \\
\text { innovation. }\end{array}$ & $\begin{array}{l}\text { Knowledge spillovers theories of } \\
\text { growth and development should } \\
\text { integrate notions of 'network } \\
\text { space' as a means of overcoming } \\
\text { the limitations imposed by } \\
\text { conceptualisations based on } \\
\text { geographic space'. }\end{array}$ & $\begin{array}{l}\text { In order to access the highest } \\
\text { quality knowledge, entrepreneurs } \\
\text { should seek to invest in a } \\
\text { balanced portfolio of networks } \\
\text { encompassing both local and } \\
\text { more global geographic } \\
\text { connections. }\end{array}$ & $\begin{array}{l}\text { The promotion of networks at a } \\
\text { range of spatial scales covering } \\
\text { intra- and inter-regional } \\
\text { connections. }\end{array}$ \\
\hline 7 & $\begin{array}{l}\text { Regional innovation rates are } \\
\text { partly a function of the spatial } \\
\text { netwiguration of the knowledge } \\
\text { entrepreneurial firms. }\end{array}$ & $\begin{array}{l}\text { Endogenous models of regional } \\
\text { growth need to incorporate } \\
\text { variables to account for inter- } \\
\text { regional flows of knowledge. }\end{array}$ & $\begin{array}{l}\text { The networks established by } \\
\text { entrepreneurs are likely to impact } \\
\text { on the growth and development } \\
\text { of the regions in which their } \\
\text { firm(s) is located as well as the } \\
\text { location of the firms and } \\
\text { organisations with which they } \\
\text { network. }\end{array}$ & $\begin{array}{l}\text { Maintain compatibility between } \\
\text { the network development of firms } \\
\text { within a region and policy } \\
\text { interventions such as those related } \\
\text { to regional innovation system } \\
\text { development. }\end{array}$ \\
\hline
\end{tabular}


Figure 1: The Knowledge Spillover Theory of Entrepreneurship

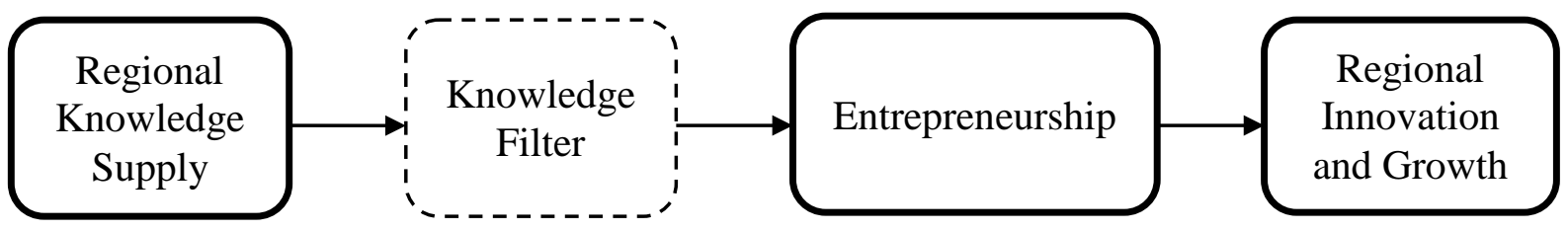

Source: Elaborated from: Audretsch and Lehmann, 2005; Audretsch and Keilbach, 2008; Audretsch et al., 2006; Acs et al., 2013. 
Figure 2: Example of Intra and Inter-Regional Knowledge Networks for Four Regions

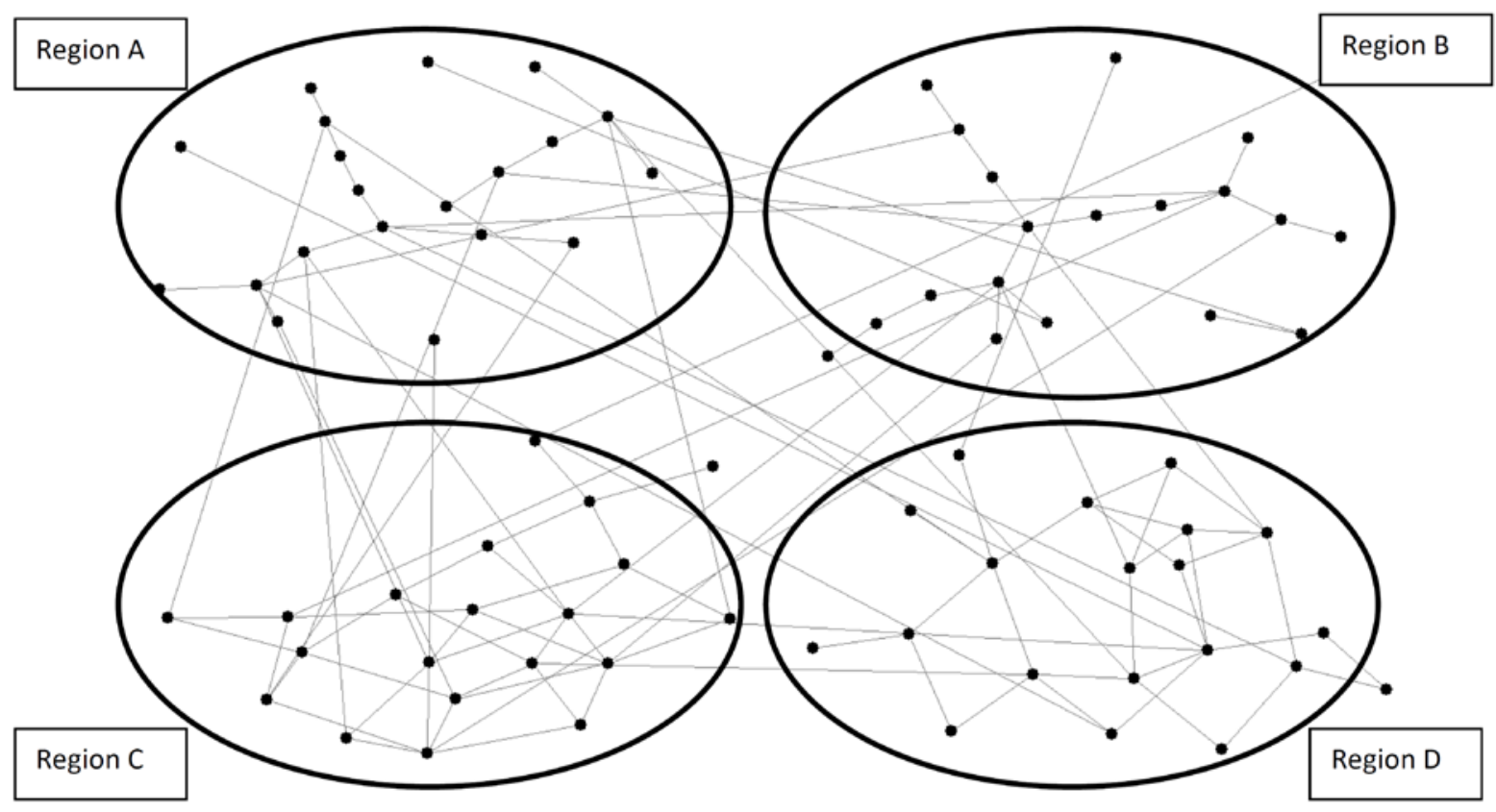


Figure 3: Network Capital and the Knowledge Spillover Theory of Entrepreneurship

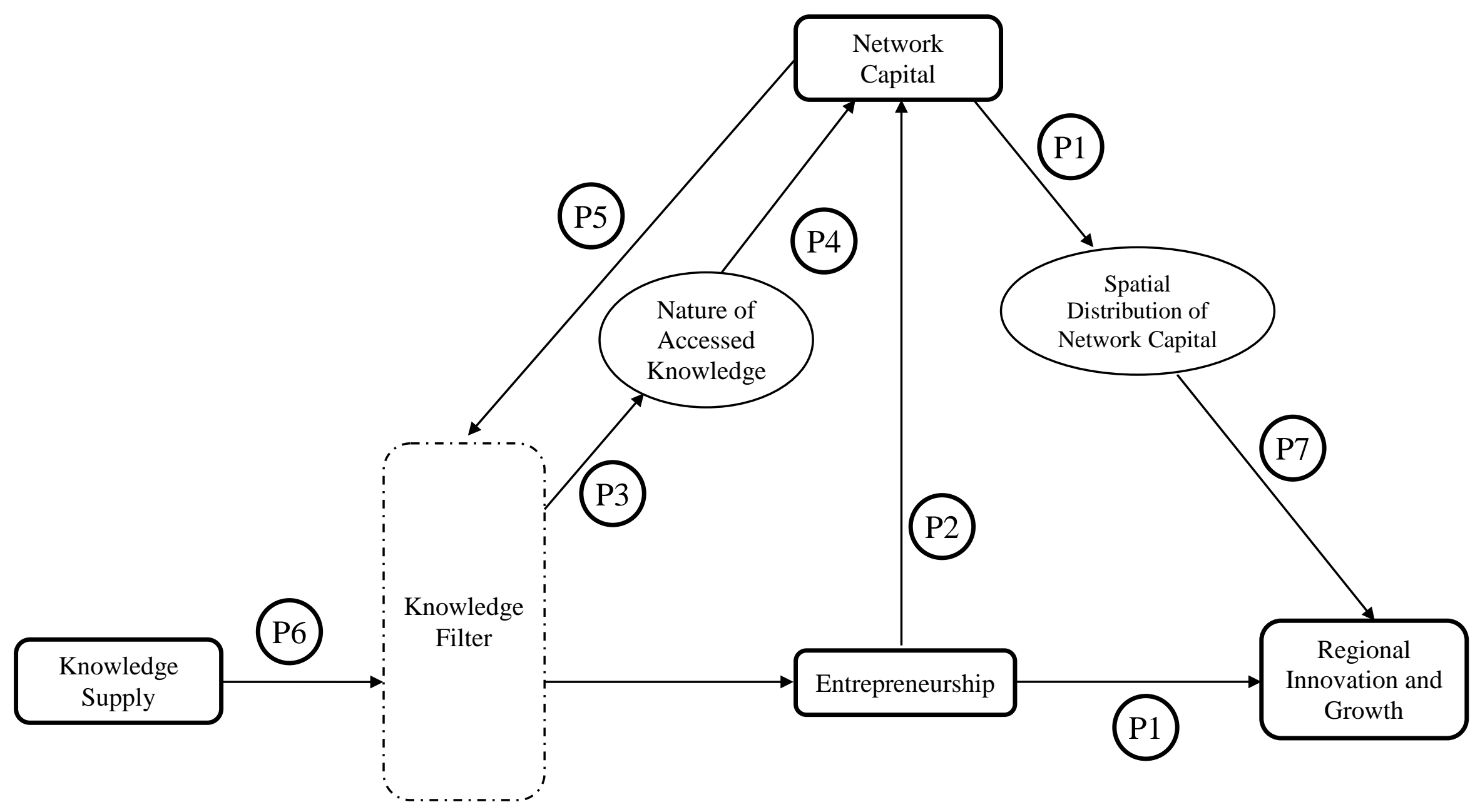

